\title{
Cytotoxicity and Transcriptomic Analysis of Silver Nanoparticles in Mouse Embryonic Fibroblast Cells
}

\author{
Sangiliyandi Gurunathan $₫$, Muhammad Qasim $₫$, Chanhyeok Park, Hyunjin Yoo, \\ Dong Yoon Choi, Hyuk Song, Chankyu Park, Jin-Hoi Kim and Kwonho Hong *
}

Department of Stem Cell and Regenerative Biotechnology and Humanized Pig Center (SRC), Konkuk Institute of Technology, Konkuk University, Seoul 05029, Korea; gsangiliyandi@yahoo.com (S.G.); qasimattock@gmail.com (M.Q.); chanhyeok.park3751@gmail.com (C.P.); hyunjinyoo7@gmail.com (H.Y.); dongyoonchoi91@gmail.com (D.Y.C.); Songh@konkuk.ac.kr (H.S.); chankyu@konkuk.ac.kr (C.P.); jhkim541@konkuk.ac.kr (J.-H.K.)

* Correspondence: hongk@konkuk.ac.kr; Tel.: +82-2-450-0560; Fax: +82-2-444-3490

Received: 25 September 2018; Accepted: 13 November 2018; Published: 16 November 2018

\begin{abstract}
The rapid development of nanotechnology has led to the use of silver nanoparticles (AgNPs) in biomedical applications, including antibacterial, antiviral, anti-inflammatory, and anticancer therapies. The molecular mechanism of AgNPs-induced cytotoxicity has not been studied thoroughly using a combination of cellular assays and RNA sequencing (RNA-Seq) analysis. In this study, we prepared AgNPs using myricetin, an anti-oxidant polyphenol, and studied their effects on NIH3T3 mouse embryonic fibroblasts as an in vitro model system to explore the potential biomedical applications of AgNPs. AgNPs induced loss of cell viability and cell proliferation in a dose-dependent manner, as evident by increased leakage of lactate dehydrogenase (LDH) from cells. Reactive oxygen species (ROS) were a potential source of cytotoxicity. AgNPs also incrementally increased oxidative stress and the level of malondialdehyde, depleted glutathione and superoxide dismutase, reduced mitochondrial membrane potential and adenosine triphosphate (ATP), and caused DNA damage by increasing the level of 8-hydroxy-2'-deoxyguanosine and the expressions of the $p 53$ and $p 21$ genes in NIH3T3 cells. Thus, activation of oxidative stress may be crucial for NIH3T3 cytotoxicity. Interestingly, gene ontology (GO) term analysis revealed alterations in epigenetics-related biological processes including nucleosome assembly and DNA methylation due to AgNPs exposure. This study is the first demonstration that AgNPs can alter bulk histone gene expression. Therefore, our genome-scale study suggests that the apoptosis observed in NIH3T3 cells treated with AgNPs is mediated by the repression of genes required for cell survival and the aberrant enhancement of nucleosome assembly components to induce apoptosis.
\end{abstract}

Keywords: cytotoxicity; oxidative stress; antioxidants; DNA damage; epigenetics; apoptosis

\section{Introduction}

Nanoparticles (NPs) are an emerging class of functional materials. Silver NPs (AgNPs) are widely used in various biomedical applications including antibacterial, antiviral, anti-inflammatory, and anticancer therapies. AgNPs are being used to produce various biomedical products where they are used to prevent infection [1]. Recent advances in nanotechnology have widened the potential applications for AgNPs. This has led to increased human exposure to AgNPs, which has prompted concern regarding their adverse biological effects [2-4]. The potential health risks associated with exposure of mammals, including humans, to AgNPs are unclear and need to be clarified. Recent studies have suggested that the toxicity due to NPs depends on the type of material and on the physical and 
chemical properties of the NPs. Toxicity is mainly influenced by various factors, which include cellular uptake of NPs and their subsequent interactions with cells [5,6].

AgNPs-mediated toxicity involves various mechanisms, in particular the production of excess reactive oxygen species (ROS). At low levels, ROS regulate various cellular functions and at higher levels induce cell death $[7,8]$. Disproportionate production of ROS induces apoptosis in a variety of human cancers, including breast cancer, ovarian cancer, and lung cancer [9-11]. Recent in vitro and in vivo studies have demonstrated the toxicity of AgNPs in a variety of cancerous and non-cancerous cells $[9,11-16]$.

The conventional physical and chemical synthesis of AgNPs is simple and can result in the production of a large quantity of material. However, the process is energy-demanding and time-consuming and is not ecofriendly because of the use of harmful chemicals. Therefore, synthesis of AgNPs without the use of hazardous chemicals and the development of AgNPs with well-controlled size and tailored morphological and physicochemical features are necessary. Only a few studies have addressed the synthesis of AgNPs using a pure flavonoid reduction of Ag and its effects on the molecular mechanism of toxicity. Bio-indicators of AgNPs' toxicity in a mammalian system would be valuable to identify. Mouse embryonic fibroblasts (MEFs) are a suitable model system to study gene ablations [17] and are also involved in wound repair and healing. AgNPs have been exploited in cancer therapy. Therefore, a comprehensive analysis of the toxicity of AgNPs effects and the molecular mechanisms of the toxicity is needed. AgNPs can modulate epigenetic dysregulation, which is involved in gene expression reprogramming, can influence the cell cycle, and can induce DNA hypermethylation following the p53 or p21 pathway, which may affect the epigenomic level [18].

Recent advancements in next-generation sequencing technologies have facilitated the use of high-throughput sequencing of DNA and RNA (the latter is termed RNA-Seq) from bulk or low-input samples [19]. The technology is now preferred over cDNA microarrays for the gene expression profiling of cells and tissues $[20,21]$. The RNA-Seq approach allows for the simultaneous analysis of a large number of genes/targets and the identification of the mechanisms of action after treatments [22-27]. However, the transcriptomic changes and cellular responses of NIH3T3 cells treated with AgNPs have not been investigated. In particular, we selected NIH3T3 as a model system for this study. Fibroblasts are ubiquitous mesenchymal cells that have important roles in wound repair and healing, and that serve as reservoirs of multipotent progenitors capable of repopulating depleted cell compartments. MEFs are frequently used to study the physiological consequences of selective gene ablations. The findings from this study using fibroblasts could provide relevant information on the potential health risks associated with human exposure to AgNPs, which should contribute to the development of safe practices for the future use of AgNPs. Understanding the mechanisms of AgNPs-mediated toxicity should also help identify avenues of protection or prevention.

This study aimed to synthesize AgNPs using myricetin. Myricetin is a flavonoid polyphenolic compound that has excellent anti-oxidant properties. We also sought to determine the effects of the synthesized AgNPs in MEFs and investigated the mechanism of action of AgNPs in regulating the growth and cellular responses of MEFs cells against AgNPs using series of cellular assays and RNA-Seq. Furthermore, gene expression profiling can be used to evaluate the molecular interactions between AgNPs and biological systems.

\section{Results and Discussion}

\subsection{Synthesis and Characterization of Silver Nanoparticles (AgNPs) Using Myricetin}

The synthesized AgNPs was characterized by five different analytical techniques to determine the physicochemical properties of the AgNPs formed using myricetin. One was ultraviolet-visible (UV-VIS) spectroscopy (Figure 1A). A preliminary analysis provided a quick and easy screening of the synthesis of the AgNPs by identifying the localized surface plasmon resonance peak typical of nano-Ag. The Ag colloid was characterized by strong absorption in the visible region at $410 \mathrm{~nm}$. The position 
of the maximum absorption and width of the absorption band provided information about the form, average size, and size distribution of the NPs. The average size of AgNPs was $50 \pm 5 \mathrm{~nm}$. As myricetin was mixed with the $\mathrm{AgNO}_{3}$ solution, a color change from pale yellow to colloidal brown was observed within a few hours. The obtained AgNPs emitted light between 400 and $700 \mathrm{~nm}$ depending on their size, shape, and morphology [28]. Flavonoids, which are present in tulsi, are able to reduce silver ions to AgNPs [29].
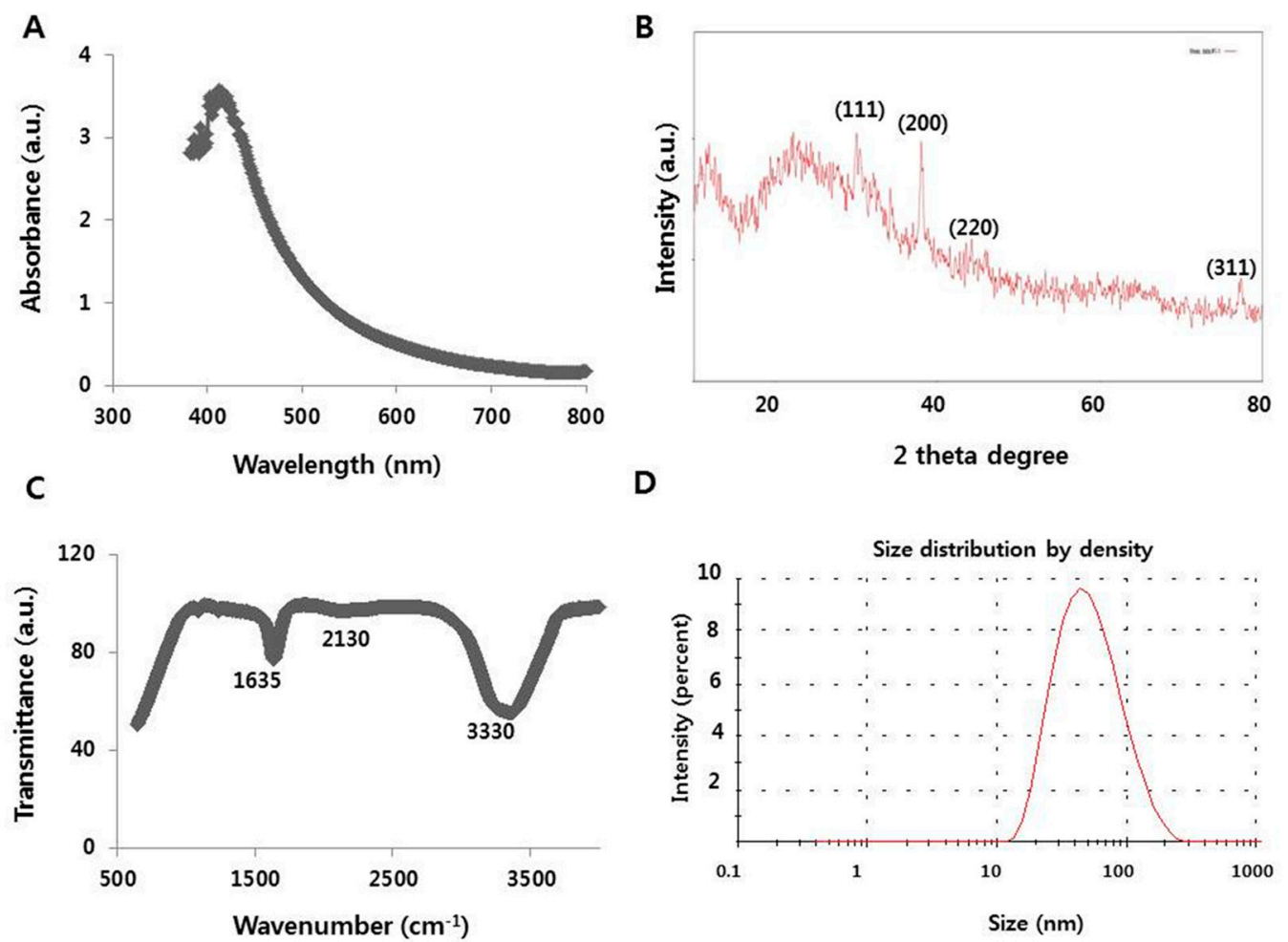

E

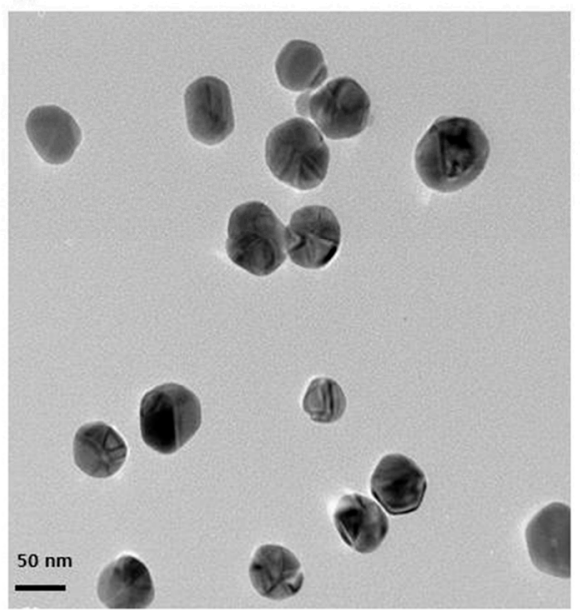

$\mathbf{F}$

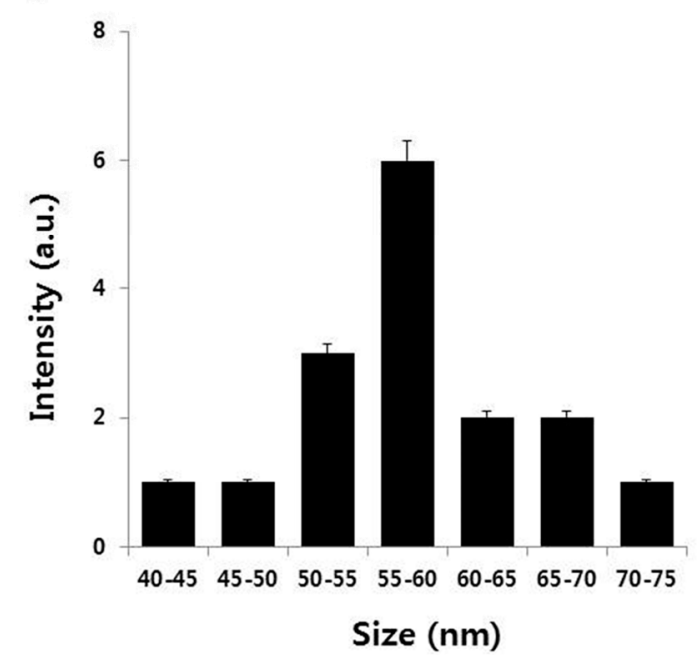

Figure 1. Cont. 
G

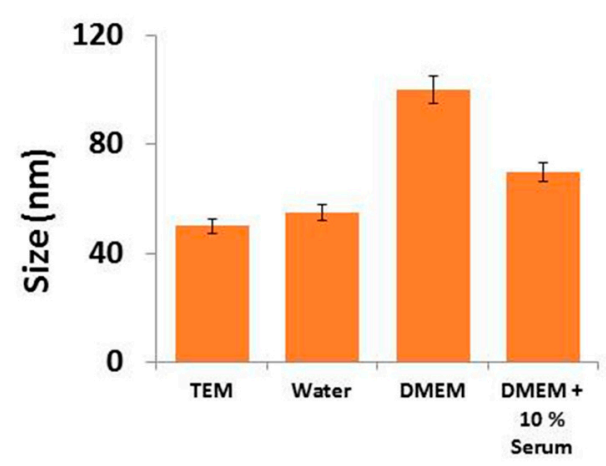

Figure 1. Synthesis and characterization of silver nanoparticles (AgNPs). (A) Ultraviolet-visible spectra of AgNPs; (B) X-ray diffraction pattern of AgNPs; (C) Fourier-transform infrared spectroscopy (FTIR) spectra of AgNP; (D) size distribution analysis of AgNPs using dynamic light scattering (DLS); (E) transmission electron microscopy (TEM) images of AgNPs; (F) histogram of the particle sizes from TEM images; (G) characterization of size distribution of AgNPs in different dispersion media.

To identify the crystalline nature and surface morphology of the synthesized AgNPs, X-ray diffraction (XRD) analysis exhibited four different peaks (Figure 1B) at approximately $38^{\circ}, 44^{\circ}, 64^{\circ}$, and $78^{\circ}$, corresponding to Bragg reflection of (111), (200), (220), and (311), respectively, which are in significant agreement with a previous report $[30,31]$. The Debye-Scherrer equation shows an average particle size of $55 \mathrm{~nm}$.

The involvement of biomolecules in the reduction of Ag ions to AgNPs was confirmed by Fourier-transform infrared (FTIR) analysis. Figure 1C depicts the FTIR spectrum of AgNPs synthesized using myricetin as reducing agent. Peaks evident at approximately 1635, 2130, and $3330 \mathrm{~cm}^{-1}$ corresponded to the $\mathrm{C}=\mathrm{C}, \mathrm{C} \equiv \mathrm{C}$, and amine $\mathrm{N}-\mathrm{H} / \mathrm{O}-\mathrm{H}$ vibration stretch. The results indicated that myricetin was the major biomolecule responsible for the reduction of Ag ions to AgNPs. The results are consistent with previous studies of the synthesis of AgNPs using plant extract and purified quercetin $[10,29,32]$.

Dynamic light scattering (DLS) analysis was performed to determine the size distribution of the AgNPs synthesized using myricetin. DLS has proven to be a suitable and simple technique for the characterization of multi-modal AgNPs suspensions and is one of the most frequently used methods to obtain an average diameter of NPs dispersed in liquids. DLS is a quick, simple, and nondestructive method that can simultaneously probe many particles [33]. The DLS size distribution of myricetin-mediated synthesized AgNPs ranged from 10 to $200 \mathrm{~nm}$ (Figure 1D). The calculated average particle size distribution of the AgNPs was $55 \mathrm{~nm}$. The broad spectrum of the DLS pattern confirmed the comparability of the particle size with the sharp SPR peak $(410 \mathrm{~nm})$ obtained in the UV-VIS spectra.

To corroborate the evidence gained from the DLS size distribution, transmission electron microscopy (TEM) was done to reveal the size and morphology of the AgNPs synthesized using myricetin (Figure 1E). The prepared particles were nearly spherical in shape and uniform in size. The mean particle size obtained using myricetin as a reducing agent was $55 \mathrm{~nm}$; the size significantly correlated with the absorption and XRD spectra. The TEM and DLS analyses both indicated a $55 \mathrm{~nm}$ particle size of the AgNPs. Sahu et al. reported that the size of NPs synthesized using hesperidin, diosmin, and naringin as the flavonoids were approximately 5-50, 5-40, and 20-80 $\mathrm{nm}$, respectively [34]. Hesperidin, naringin, and diosmin-derived AgNPs were oval-shaped, polydisperse, and hexagonal in shape, respectively. Prathna et al. described an average size of $50 \mathrm{~nm}$ using citrus, tulsi, and quercetin plant extract produced 50,14.6, and $11.35 \mathrm{~nm}$, respectively [29,35]. Our findings suggest that myricetin produces AgNPs with an average size of 50-60 nm. These particles would easily penetrate cells and release Ag ion faster than larger particles. 
To further confirm the size distributions observed in TEM, we performed size distribution analysis in water, Dulbecco's Modified Eagle's Medium (DMEM) media, and DMEM with 10\% fetal bovine serum (FBS) using a dynamic light scattering assay. It was found that the average size of AgNPs was $50 \pm 5.0,55 \pm 6.0,100 \pm 10.0$ and $70 \pm 8.0 \mathrm{~nm}$ in TEM, water, DMEM media, and DMEM with $10 \%$ serum, respectively (Figure 1G). The results suggest that AgNPs particles dissolved in DMEM media exhibited a larger size distribution compared to AgNPs dissolved in water, whereas DMEM media with $10 \%$ FBS showed slight variation compared to DMEM alone. All these data suggest that the size distributions of AgNPs depend on the Brownian motion found in different dispersion media. Next, we analyzed the zeta potential values of AgNPs in water, DMEM, and DMEM with 10\% serum, with the zeta potential values in agreement with previous observations. As shown in Table 1, absolute zeta potential values were higher when measured in DMEM or DMEM with $10 \%$ serum compared to measurements taken in media without serum.

Table 1. Zeta potential of AgNPs in different dispersion media.

\begin{tabular}{cc}
\hline Solvent & Zeta Potential \\
\hline Water & $-25.2 \pm 0.1$ \\
DMEM & $20.5 \pm 1.5$ \\
DMEM $+10 \%$ serum & $11.5 \pm 2.2$ \\
\hline
\end{tabular}

\subsection{AgNPs Reduce the Viability and Cell Proliferation of NIH3T3 Cells}

Cell viability was determined using CCK-8. AgNPs significantly inhibited NIH3T3 viability in a dose-dependent manner (Figure 2A). Similarly, results from a cell proliferation assay showed that AgNPs significantly inhibited NIH3T3 cell proliferation, also in a dose-dependent cytotoxic manner (Figure 2B). Lee et al. [4] demonstrated that NIH3T3 cells treated for $24 \mathrm{~h}$ with AgNPs displayed alterations in cell morphology that included cell shrinkage, few cellular extensions, increased floating cells, accumulation of AgNPs clusters in the cytoplasm, and a dose-dependent decrease of AgNPs' cell viability [4]. Several other studies reported that AgNPs induced toxicity by entering the cytoplasm and mitochondria through perturbations of the plasma membrane. The plasma membrane disruption increased the leakage of lactate dehydrogenase (LDH) and the generation of ROS increased cytotoxicity in a variety of human cancer cells [10,16,36]. Lee et al. [4] found that AgNPs induced ROS and heme oxidase-1 mRNA expression in NIH3T3 cells. Collectively, the data indicate the AgNPs synthesized using myricetin have dose-dependent effects on NIH3T3 cell viability and proliferation.

To determine the effectiveness of AgNPs, we performed a cell viability assay in NIH3T3 cells with various concentrations of $\mathrm{AgNO}_{3}$ and myricetin both used as a positive control. The viability of NIH3T3 cells decreased significantly compared to that of the negative control (Figure 3A). Notably, $\mathrm{AgNO}_{3}$ exhibited enhanced toxicological effects on NIH3T3 cells by decreasing cell proliferation (Figure 3B) compared to the effects of AgNPs, which is due to the fast release of silver ions from $\mathrm{AgNO}_{3}$ Similarly, we studied the effect of myricetin on cell viability and cell proliferation in NIH3T3 cells. The results displayed that there is no significant effect on cell viability and cell proliferation in concentrations up to $100 \mu \mathrm{g} / \mathrm{mL}$ (Figure $4 \mathrm{~A}, \mathrm{~B}$ ). This indicates that the concentrations of myricetin selected for the synthesis of AgNPs had no effect on cell viability and cell proliferation; the decline in cell viability and cell proliferation was merely due to AgNPs. 
A

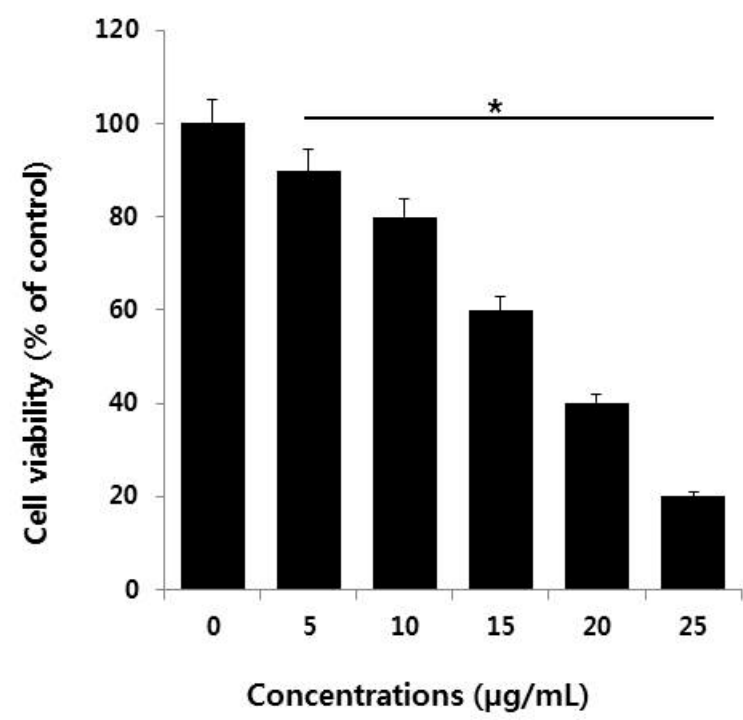

B

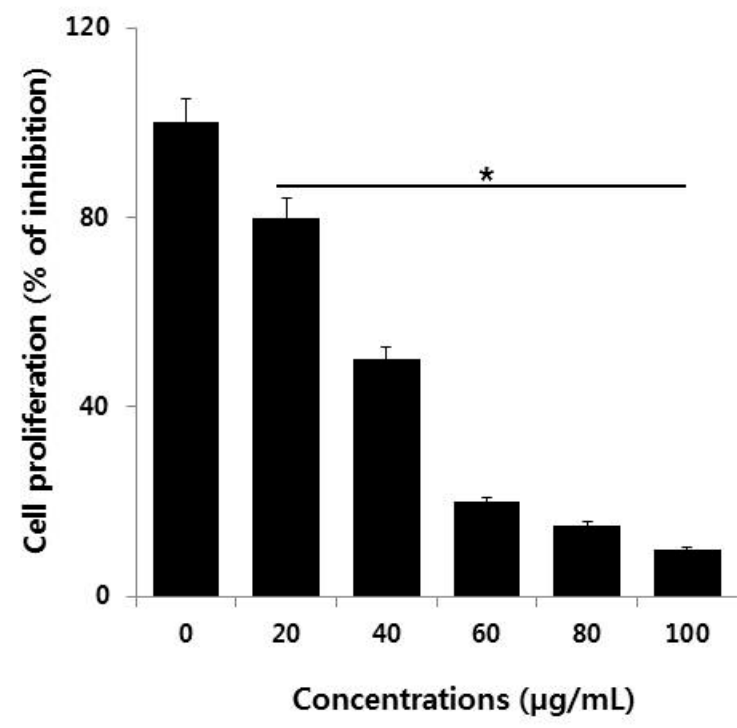

Figure 2. Cell viability and proliferation assessment of AgNPs in NIH3T3 cells. (A) Viability of NIH3T3 cells was determined $24 \mathrm{~h}$ after exposure to different concentrations of AgNPs using the CCK-8 assay. (B) Cell proliferation assay was performed using the BrdU cell proliferation assay. The results are expressed as the mean \pm standard deviation of three independent experiments. There was a significant difference in the ratio for AgNP-treated cells compared to untreated cells according to a Student's $t$-test $\left({ }^{*} p<0.05\right)$.

A

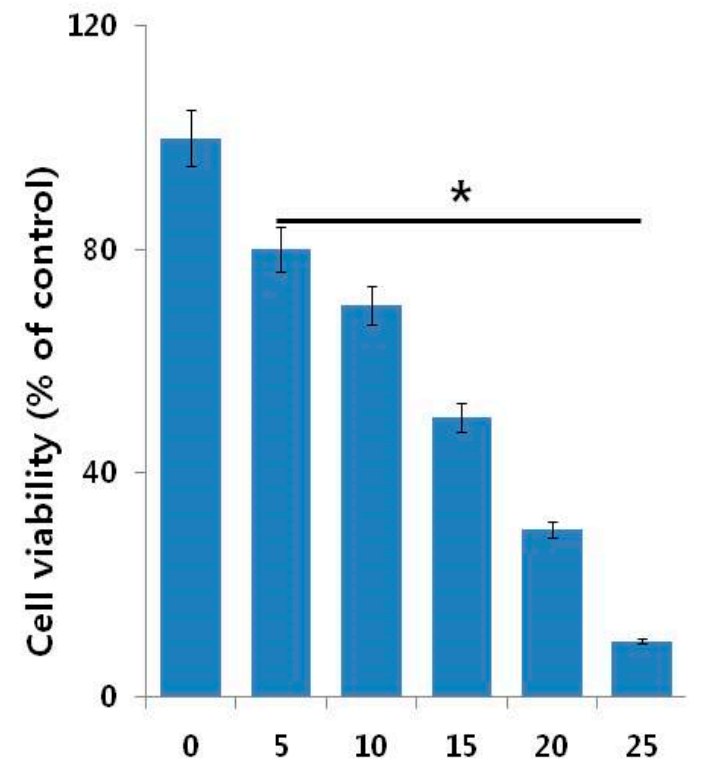

Concentrations $(\mu \mathrm{g} / \mathrm{mL})$

B

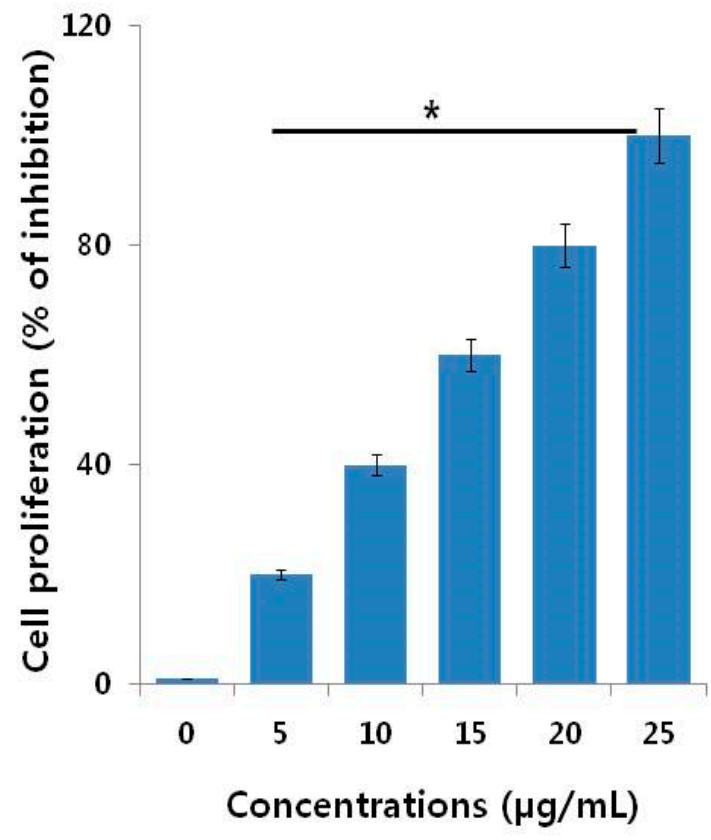

Figure 3. Cell viability and proliferation assessment of Ag ions in NIH3T3 cells. (A) Viability of NIH3T3 cells was determined $24 \mathrm{~h}$ after exposure to different concentrations of Ag ions using the CCK- 8 assay. (B) Cell proliferation assay was performed using the BrdU cell proliferation assay. The results are expressed as the mean \pm standard deviation of three independent experiments. There was a significant difference in the ratio of AgNP-treated cells compared to untreated cells according to a Student's $t$-test $\left({ }^{*} p<0.05\right)$. 
A

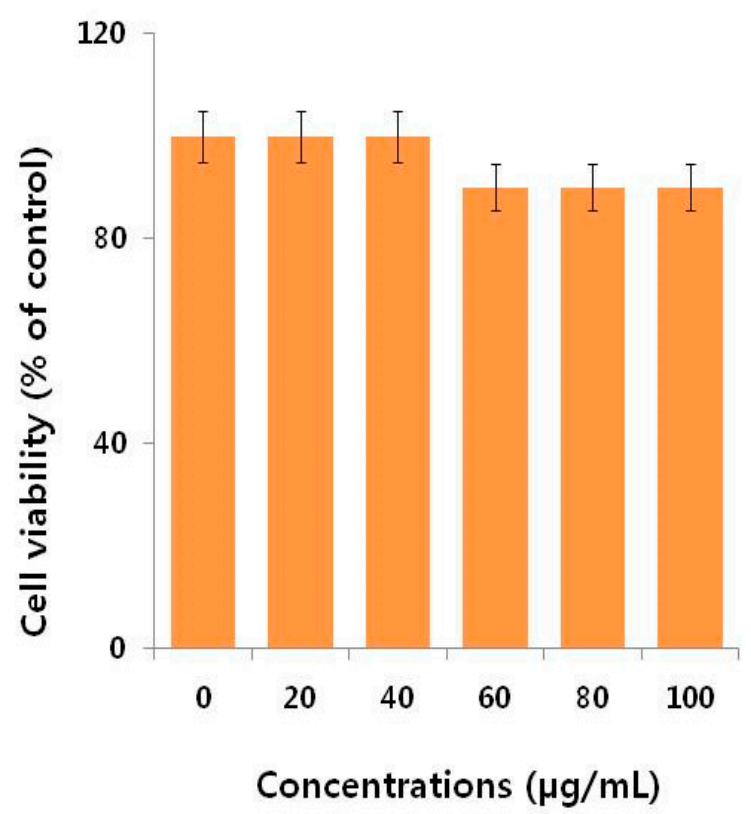

B

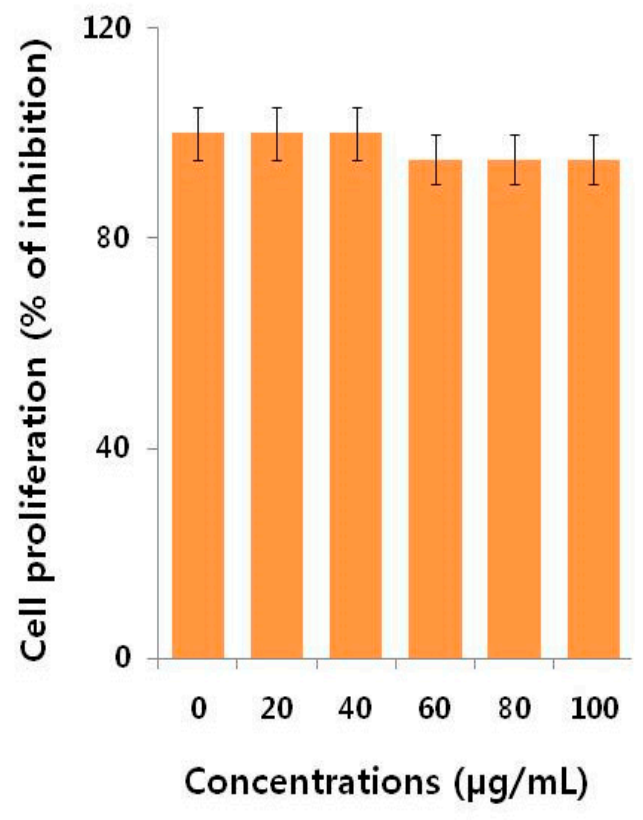

Figure 4. Cell viability and proliferation assessment of myricetin in NIH3T3 cells. (A) Viability of NIH3T3 cells was determined $24 \mathrm{~h}$ after exposure to different concentrations of myricetin using the CCK-8 assay. (B) Cell proliferation assay was performed using the BrdU cell proliferation assay. The results are expressed as the mean \pm standard deviation of three independent experiments.

\subsection{AgNPs Induce Cytotoxicity in NIH3T3 Cells}

Cytotoxicity can be measured by the level of LDH released from cells. Normally, LDH is a cytoplasmic enzyme that is sequestered inside viable cells that have intact plasma membranes. Upon membrane damage, LDH can be released. The amount of LDH released from cells is directly proportional to the damage caused by molecules, including AgNPs. A significant effect was observed on extracellular LDH concentration even at the lowest concentration of AgNPs $(5 \mu \mathrm{g} / \mathrm{mL})$ (Figure 5A). This and higher concentrations produced severe leakage of LDH from NIH3T3 cells in a dose-dependent manner, suggesting that AgNPs disrupted the plasma membrane integrity of the cells, as discussed above, which is a major factor for cytotoxicity. Similarly, human and rat embryonic neural stem cells (NSCs) exposed to $\geq 5 \mu \mathrm{g} / \mathrm{mL}$ AgNPs also display significantly increased leakage of LDH [37].

Next, to corroborate the results obtained from the LDH assay, we assessed the activities of proteolytic enzymes associated with cell death or viability. The proteolytic activity is very sensitive and dependent on membrane integrity, and thus can be a good indicator of the damage caused by cytotoxic agents. To further substantiate the loss of membrane integrity, we measured cell-protease activity in NIH3T3 cells by cell viability ratio [38]. The results showed that a significant loss of viability occurred with increasing concentrations of AgNPs (Figure 5B). 
A

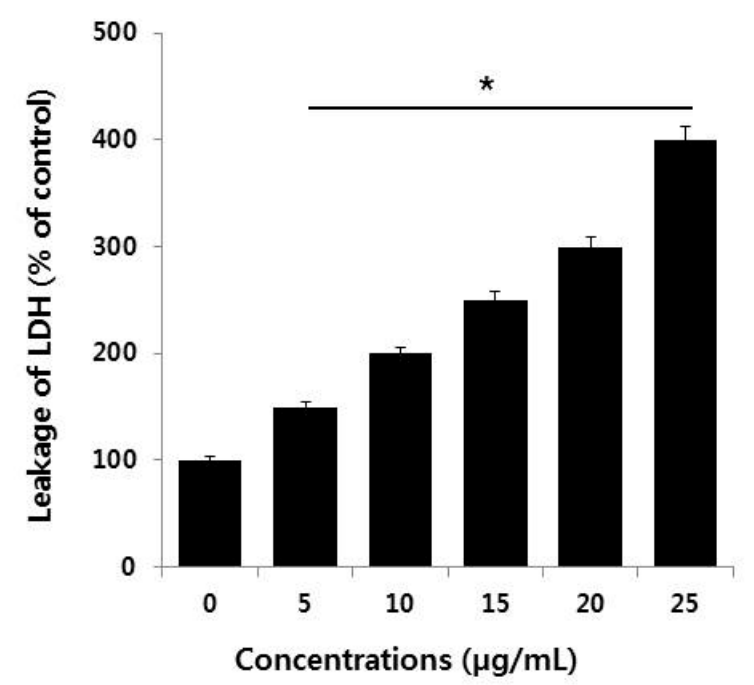

B

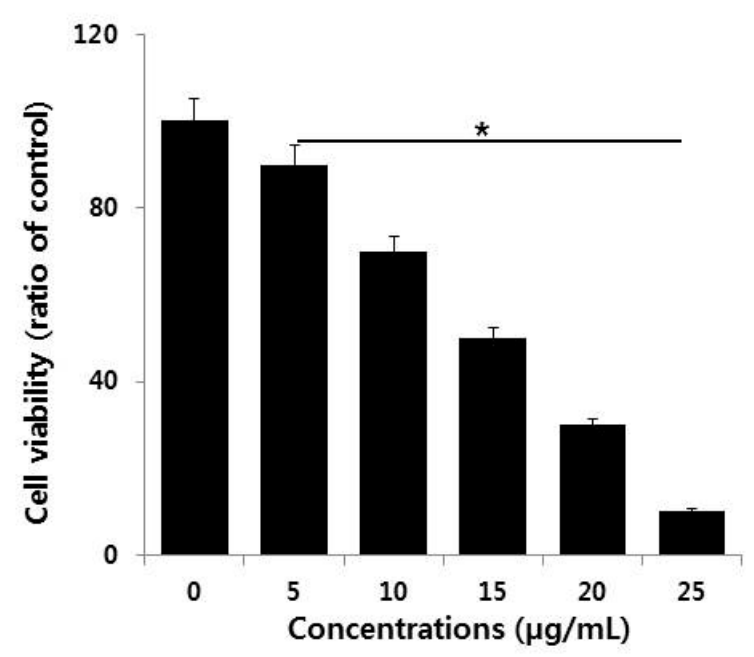

Figure 5. Measurement of LDH leakage and cell death protease activity in NIH3T3 cells. (A) LDH activity was measured at $490 \mathrm{~nm}$ using the LDH cytotoxicity kit. (B) The level of dead-cell protease was determined by the CytoTox-Glo cytotoxicity assay. The results are expressed as the mean \pm standard deviation of three independent experiments. There was a significant difference in the ratio of AgNP-treated cells compared to untreated cells according to a Student's $t$-test $\left({ }^{*} p<0.05\right)$.

\subsection{Cellular Uptake and Internalization of $A g N P S$}

To determine the cellular uptake of AgNPs by NIH3T3 cells, the cells were incubated with $15 \mu \mathrm{g} / \mathrm{mL}$ of AgNPs for $24 \mathrm{~h}$. The TEM images of control cells showed a typical cellular structure and membranous organelles (Figure 6A), whereas micrographs of AgNPs with $15 \mu \mathrm{g} / \mathrm{mL}$ of AgNPs treated cells showed AgNPs in the cytoplasm (Figure 6B); in particular, AgNPs were taken up and contained mainly within membrane-bound structures (Figure 6C). Cells exposed to AgNPs exhibit typical autophagosomes (black thick arrow) with double membranes and enclosed cellular contents compared to untreated cells. In addition, when compared to the unexposed control cells, the treated cells showed many multivesicular and membrane-rich autophagosomes in close proximity to each other, indicating that AgNPs could induce autophagosome formation at the ultrastructural level [11].

\subsection{AgNPs Induce Oxidative Stress by Increased Levels of ROS and Malondialdehyde (MDA)}

Of the possible mechanisms proposed for AgNPs-induced toxicity, the production of excess ROS seems to be the most important contributor for nanotoxicity or nanocytotoxicity. ROS generation is important in apoptosis induced by AgNPs. Therefore, we examined the effect of AgNPs on ROS generation in NIH3T3 cells using the $2^{\prime}, 7^{\prime}$-dichlorofluorescin diacetate $\left(\mathrm{H}_{2} \mathrm{DCF}-\mathrm{DA}\right)$ assay. After a 24-h exposure, increasing concentrations of AgNPs $(5-25 \mu \mathrm{g} / \mathrm{mL})$ significantly increased ROS levels compared with the control (Figure 7A). Although ROS is essential for physiological activities, excess levels are potentially destructive $[39,40]$. The present results highlight the potential of AgNPs to induce ROS production in NIH3T3 cells. Excess ROS can injure lipids, proteins, and DNA in cells, and eventually induce apoptosis [41]. AgNPs interact with cell membrane proteins via the avid affinity of Ag for sulfur moieties. The resulting ROS production can cause the aforementioned destruction, including apoptosis and inhibition of cell proliferation [42-44]. 


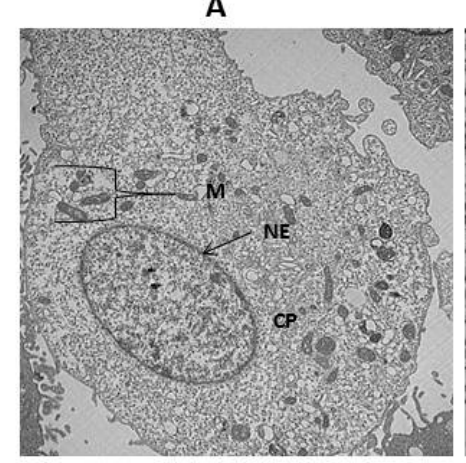

B

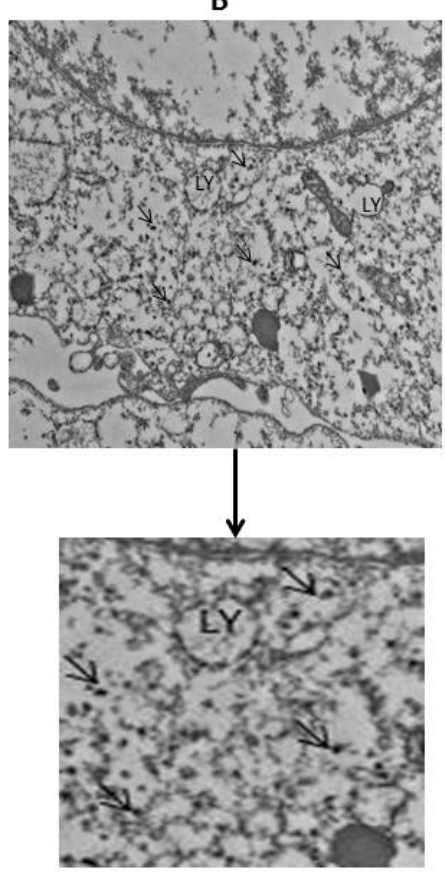

C

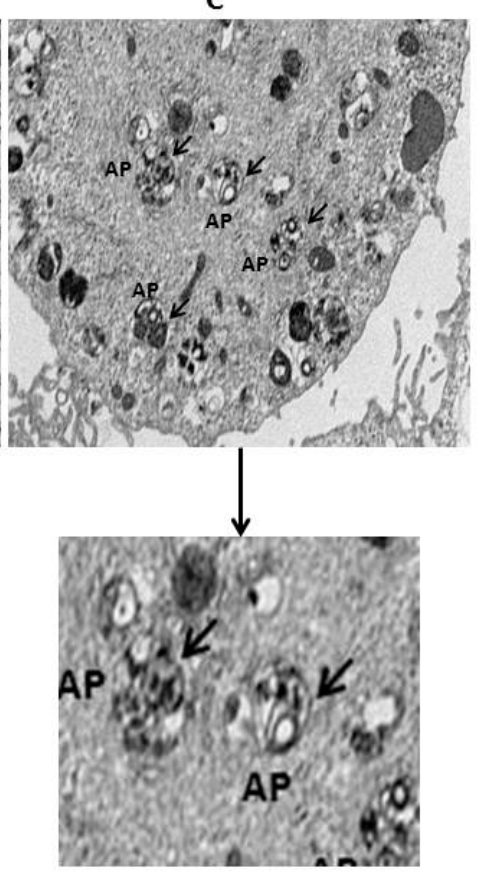

Figure 6. Intracellular localization of AgNPs and accumulation of autophagosomes and autolysosomes. NIH3T3 cells were treated with silver nanoparticles (AgNPs) for $24 \mathrm{~h}$ and then processed for transmission electron microscopy (TEM) sections. TEM images of NIH3T3 cells without AgNPs (A); internalization of AgNPs (thin black arrow) (B); and AgNPs induces accumulation of autophagosomes (thick black arrow) (C). M-Mitochondria; NE-Nuclear envelope; CP-Cytoplasm; LY-lysosomes; AP-Autophagosomes, scale bar: $2 \mu \mathrm{m}$.

A

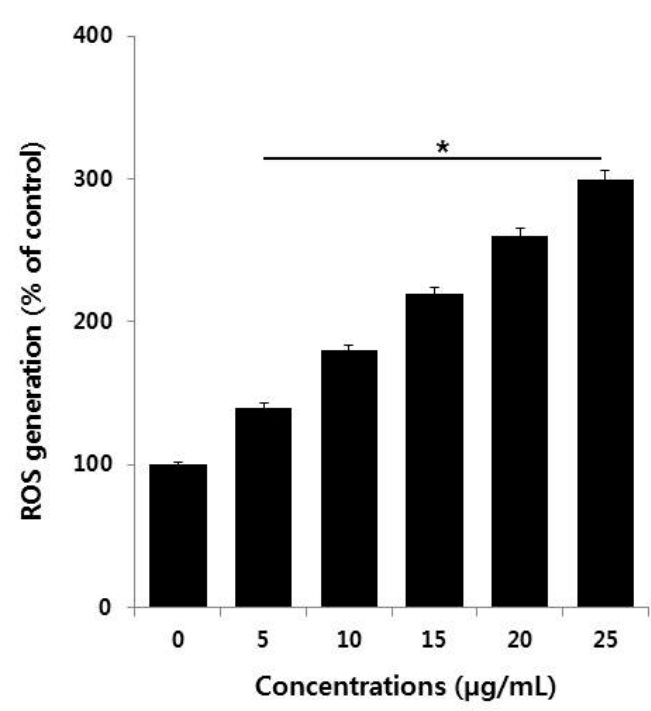

B

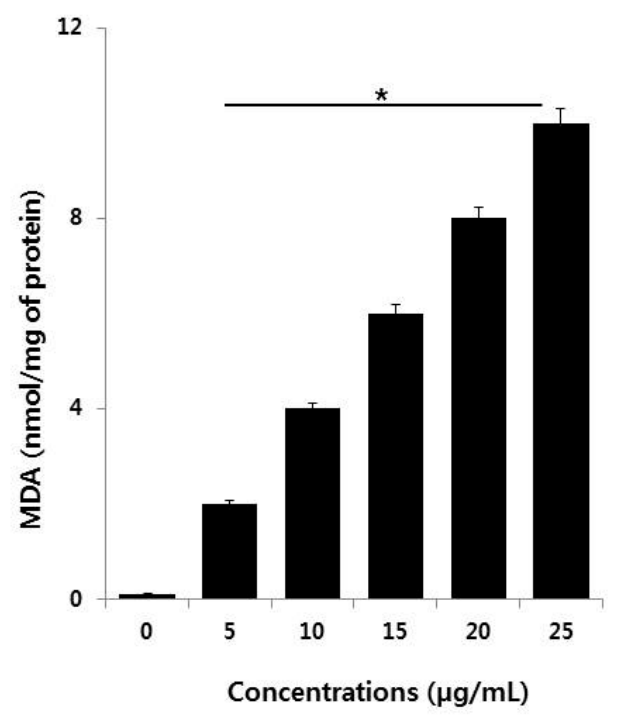

Figure 7. Measurement of ROS generation and malondialdehyde (MDA) in NIH3T3 cells. (A) NIH3T3 cells were treated with or without AgNPs for $24 \mathrm{~h}$, and ROS generation was measured using DCFH-DA. (B) NIH3T3 cells were treated with AgNPs for $24 \mathrm{~h}$. Lipid peroxidation was determined by the reaction of MDA with thiobarbituric acid to form a colorimetric $(532 \mathrm{~nm}$ )/ fluorometric (excitation and emission wavelength of 532 and $553 \mathrm{~nm}$, respectively) product, whose quantity was proportional to the MDA present. The results are expressed as the mean \pm standard deviation of three independent experiments. There was a significant difference in the ratio of AgNP-treated cells compared to untreated cells according to a Student's $t$-test $\left({ }^{*} p<0.05\right)$. 
To confirm the effect of ROS excess on lipid peroxidation, we analyzed the level of MDA in NIH3T3 cells treated with various concentrations of AgNPs for $24 \mathrm{~h}$. AgNPs increased the level of MDA in NIH3T3 cells in a dose-dependent manner (Figure 7B). In BF-2 cells carbon NPs, such as graphene, induce increases in lipid peroxidation that are related to the concentration of graphene oxide and can become significant [45]. Other authors reported that long-term exposure of human lung cells to AgNPs produced upregulation of the expression of genes encoding anti-oxidant enzymes like glutathione-S-transferases, which are involved in clearing lipid peroxidation products [46]. AgNPs have the potential to induce cellular responses involved in cell survival or cell death pathways [4,47]. Several studies found that AgNPs could potentially elevate ROS generation and MDA levels in a variety of cells $[13,48,49]$. NIH3T3 cells displayed similar sensitivity in the AgNPs-induced loss of cell viability, cell proliferation, and cell death by increased oxidative stress and lipid peroxidation.

\subsection{Effect of AgNPs on Antioxidants}

The imbalance between oxidants and antioxidants creates oxidative stress, in which the level of oxidants in cells becomes extremely high. Maintenance of the level of the reduced and oxidized (redox) state is crucial for cell viability, activation, proliferation, and organ function [50]. For example, reduced glutathione (GSH) and superoxide dismutase (SOD) are the major endogenous antioxidant scavengers. They are important in scavenging free radicals created during exposure to AgNPs. Increased oxidative stress is due to the depletion of GSH, altered level of SOD, and catalase activity in cells [51,52]. Based on this background, we examined the influence of AgNPs on the level of the GSH and SOD antioxidants. NIH3T3 cells treated with AgNPs displayed a dose-dependent decrease of GSH and SOD compared to untreated cells (Figure 8A,B). AgNPs reduced the level of GSH by increasingly inhibiting the intracellular enzyme responsible for GSH synthesis and also reduce mitochondrial membrane potentiality in buffalo rat liver (BRL) 3A rat liver [53]. Similarly, AgNPs are cytotoxic via the mitochondrial pathway by reducing GSH, enhancing lipid peroxidation, and enhancing the expression of ROS responsive genes, which cause DNA damage, apoptosis, and necrosis [44]. AgNPs were reported to cause cytotoxicity and genotoxicity through decreased mitochondrial membrane potential and reductions in the activities of SOD, catalase (CAT), glutathione peroxidase (GPx), glutathione-S-transferase (GST), and glutathione reductase (GR), as well as total GSH level in Chinese Hamster Ovary cells [54]. A recent study reported that the combination of palladium NPs and tubastatin-A enhances apoptosis in human breast cancer cells through reductions in the levels of various antioxidants markers, including GSH, SOD, and CAT, with oxidative stress ultimately resulting from the excess ROS [55].

\subsection{Effect of AgNPs on Mitochondrial Dysfunction and ATP Generation}

The mitochondrion is crucial in the induction of the signal for cell apoptosis. AgNPs can disrupt mitochondrial integrity, which leads to a loss of mitochondrial membrane permeability. This loss may regulate c-Jun N-terminal kinase-mediated, caspase-dependent apoptosis [53]. We assessed the effects of AgNPs on mitochondrial membrane potential (MMP) in NIH3T3 cells. MMP was determined in AgNPs-treated NIH3T3 cells ( $5-25 \mu \mathrm{g} / \mathrm{mL}$ for $24 \mathrm{~h}$ ) using the JC- 1 cationic fluorescent dye as previously described [56]. The treated cells displayed significantly altered MMP; the JC-1 aggregate/monomer ratio was decreased in AgNPs-treated cells compared to control (Figure 9A). Thus, the reductions in cell viability and proliferation and increased toxicity described in preceding sections of this paper were likely associated with mitochondrial dysfunction. AgNPs could impair mitochondrial function prior to their penetration and accumulation in the mitochondrial membrane and it can inhibit neurite outgrowth and reduces the cell survival of premature neurons and glial cells [57]. AgNPs cause cytotoxicity in Caco-2 cells through mitochondrial depolarization and depletion of antioxidants, such as GSH, and the reduction of MMP in BRL 3A rat liver cells [53,58]. AgNPs play significant role to impair mitochondrial 
pathway by modulating pro and anti-oxidants [44]. Our findings suggest that loss of MMP is a major mechanism of toxicity through crosstalk between mitochondria and other cell components $[11,59,60]$.

A

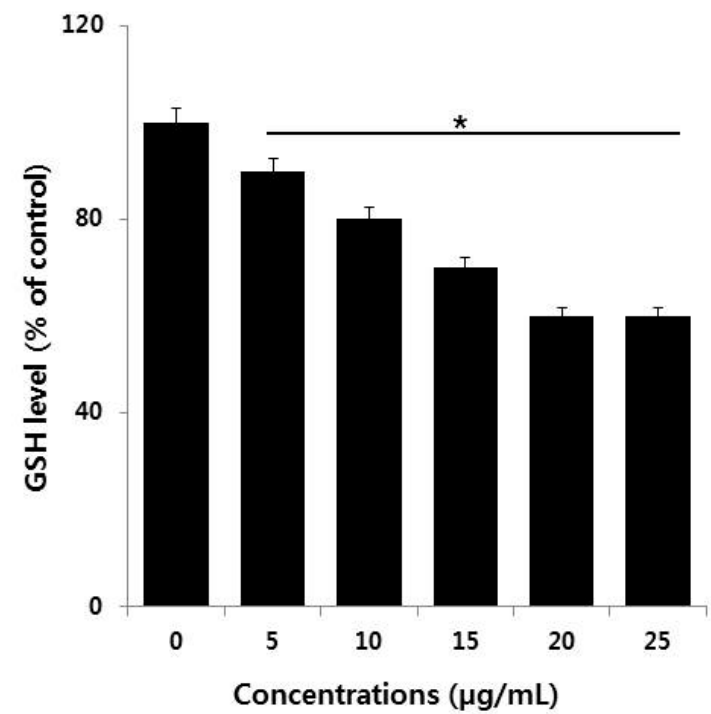

B

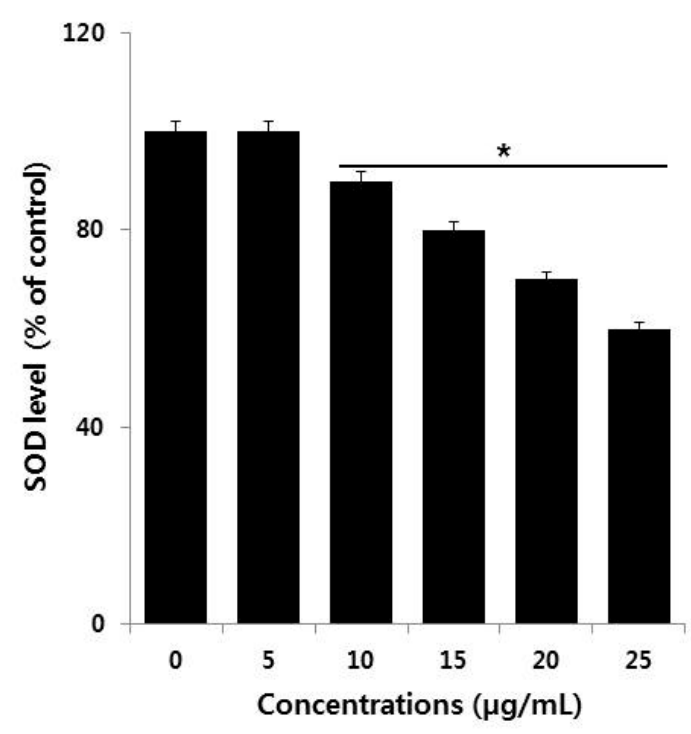

Figure 8. Measurement of antioxidants in NIH3T3 cells. Cells were treated with various concentrations of AgNPs for $24 \mathrm{~h}$. After incubation, the cells were harvested, washed twice with ice-cold PBS, and disrupted by ultrasonication for $5 \mathrm{~min}$ on ice. (A) The concentration of glutathione (GSH) was expressed as milligram per gram of protein. (B) The specific activity of superoxide dismutase (SOD) was expressed as unit per milligram of protein. The results are expressed as mean \pm standard deviation of three independent experiments. There was a significant difference in the ratio of AgNP-treated cells compared to untreated cells according to a Student's $t$-test $\left({ }^{*} p<0.05\right)$.

A

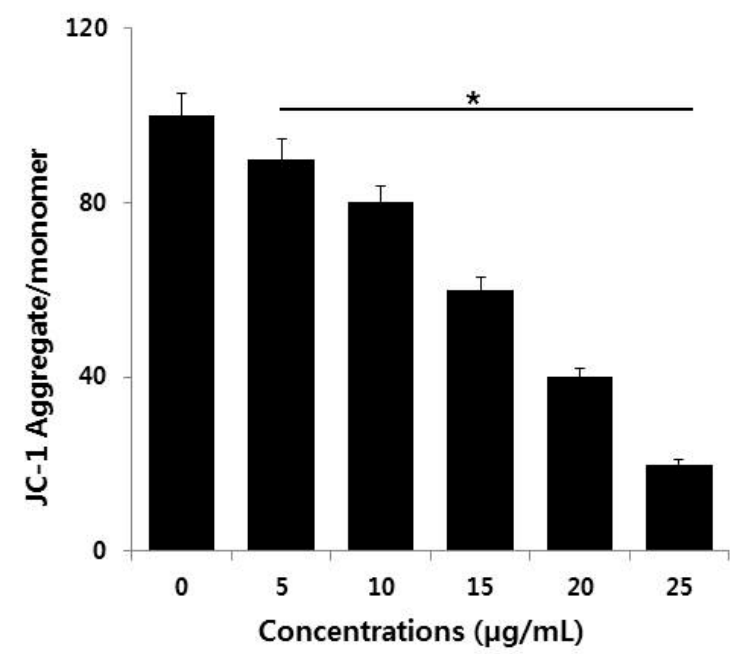

B

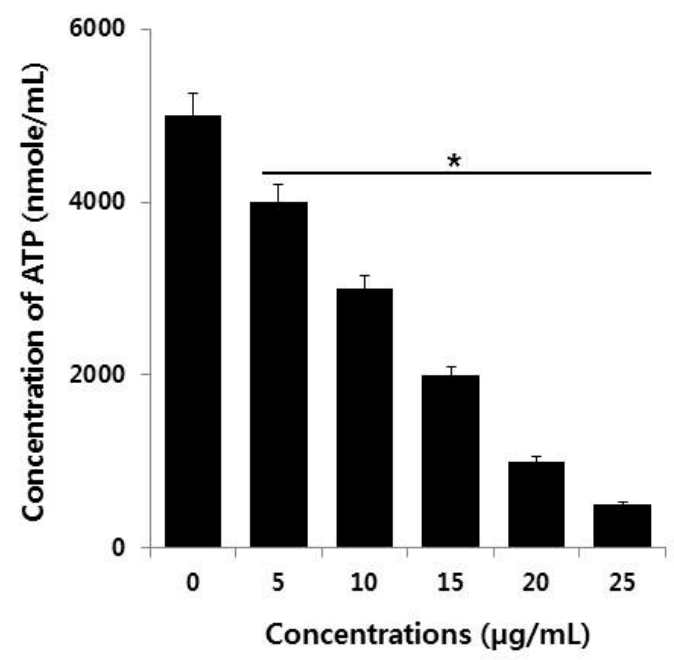

Figure 9. Effect of AgNPs on MMP and ATP. (A) NIH3T3 cells were treated with AgNPs for $24 \mathrm{~h}$. The changes in mitochondrial membrane potential (MMP) were determined using the cationic fluorescent dye JC-1. (B) The ATP level was measured in NIH3T3 cells exposed to AgNPs for $24 \mathrm{~h}$. The results are expressed as the mean \pm standard deviation of three independent experiments. There was a significant difference in the ratio of AgNP-treated cells compared to untreated cells according to a Student's $t$-test $\left({ }^{*} p<0.05\right)$. 
The MMP is impacted in bioenergy disorders. It is important for ATP production and is required for biogenesis of Fe-S clusters, to drive the mitochondrial import of many nuclear-encoded proteins, and for calcium transport [61-63]. We investigated whether the loss of MMP could influence the level of ATP production in AgNP-treated cells by measuring the level of ATP in AgNP-treated and untreated cells. AgNP-treated cells displayed significantly and dose-dependently reduced ATP production compared to control cells (Figure 9B). The results showed that the synthesis of ATP was compromised by AgNP treatment. The findings indicated the declining of synthesis of ATP is similar to drug-induced mitochondrial poisoning inherited mitochondrial diseases [64]. Damage to mitochondria leads to decreased level of ATP production [65]. Alteration of MMP is the potential cause for mitochondrial dysfunction, which is the major factor for the generation of ROS, lipid peroxidation, and susceptibility to apoptosis [66]. AgNPs-induced apoptosis involves the mitochondrial pathway; NIH3T3 fibroblast cells and human Chang liver cells treated with AgNPs causes release of cytochrome c release into the cytoplasm and translocation of Bax to mitochondria. Moreover, AgNPs may promote alterations in the MMP leading to stress-induced apoptotic cell death $[13,16,51,53]$. Thus, AgNPs could impair mitochondrial function and reduce the generation of ATP, which eventually leads to cell death.

\subsection{AgNPs Cause DNA Damage in NIH3T3 Cells}

Excess ROS generation can permanently damage cellular membrane lipids, as well as proteins and DNA. 8-OhdG can be used to measure the effect of endogenous oxidative damage to DNA and as a factor of the initiation and promotion of carcinogenesis [67]. To evaluate the effect of AgNP-induced ROS on DNA damage in NIH3T3 cells, 8-oxo-dG levels were determined. A 24-h exposure of NIH3T3 cells to various concentrations of AgNPs increased oxidative DNA damage, as indicated by a significant elevated level of 8-oxo-dG production (Figure 10A). A prior study demonstrated that AgNPs could induce laddering of DNA and DNA fragmentation in Dalton's lymphoma ascites cell lines [68]. Similarly, a 24-h exposure of rat NSCs to $5 \mu \mathrm{g} / \mathrm{mL}$ AgNPs increased the level of 8-oxo-dG. AgNP-induced oxidative stress can stimulate various genotoxic effects in variety of human cells $[53,69,70]$. Collectively, our findings suggest that AgNPs potentially induce oxidative damage to DNA due to an increased generation of ROS. Therefore, ROS is a major factor of AgNP-induced cytotoxicity in NIH3T3 cells.

The mechanisms of AgNP toxicity include oxidative stress, DNA damage, and apoptosis in numerous human cell lines in vitro $[53,69,70]$. To further substantiate AgNP-induced DNA damage in NIH3T3 cells, we measured the expression of representative genes responsible for DNA damage (p53 and p21) in AgNP-treated and untreated cells. AgNP treatment resulted in increased expression of p53 and p21 compared to untreated cells (Figure 10B,C). These elevations might contribute to AgNPs-mediated oxidative stress, which is the major cause of DNA damage. Previous studies demonstrated that oxidative stress can induce DNA fragmentation, single-strand breaks in human breast cancer cells, and double-strand breaks in ovarian cancer cells [9,71]. Another study reported that HT22 hippocampal neuronal cells exposed to AgNPs for $24 \mathrm{~h}$ displayed effects on various cellular processes by alteration of p53, p21, and lamin B1, as well as methylation changes [18]. The increased level of p53 and p21 noted by us and others is responsible for DNA damage and may also account for the observed loss of cell viability and inhibition of cell proliferation. Previous report suggest that AgNPs induce cell death via activation of p53, p-Erk1/2, and caspase-3 signaling, and downregulation of Bcl-2. Our findings also confirmed that NIH3T3 cells treated with AgNPs displayed a dose-dependent increase in the expression of caspase-3 (Figure 10D). Caspase-3 is a typical mediator of cell death. AgNPs inhibit vascular endothelial factor activated cell survival and proliferation by suppression of AKT phosphorylation and induction of caspase 3 activity in bovine retinal endothelial cells [30,72]. Similarly, AgNPs cause cytotoxicity in a dose-dependent manner in cerebellum granule cells activated by the induction of caspase- 3 activation, oxidative stress, reduction of antioxidants, and intracellular calcium levels [73]. Extreme level of ROS production causes the upregulation of mitogen-activated protein kinase (MAPK) P38, downregulation of total 
$\mathrm{AKT}$, and the significantly increased expressions of caspase-3, H2A histone family member $\mathrm{X}(\mathrm{H} 2 \mathrm{X})$, p-p53, and total p53 [74]. Collectively, our findings suggest that AgNPs can induce apoptosis through the activation of $\mathrm{p} 53, \mathrm{p} 21$, and the caspase-3-mediated signaling pathway.
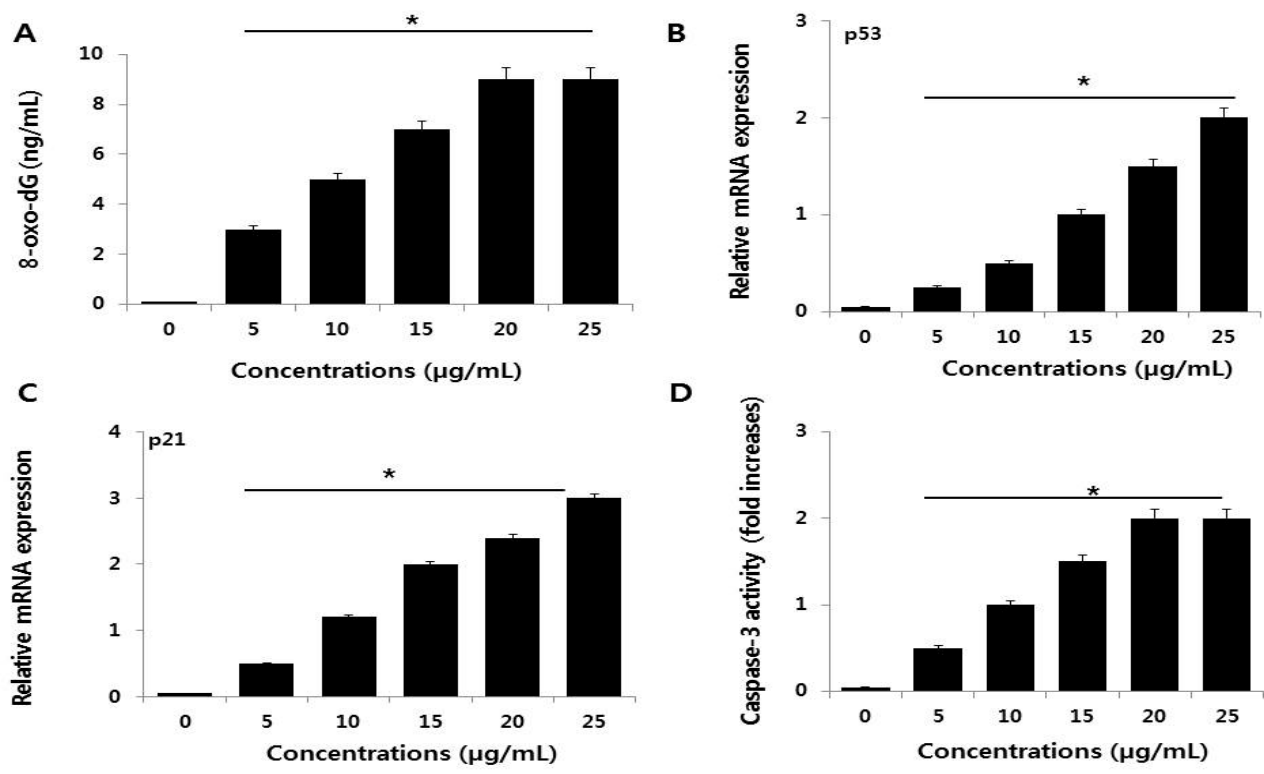

D
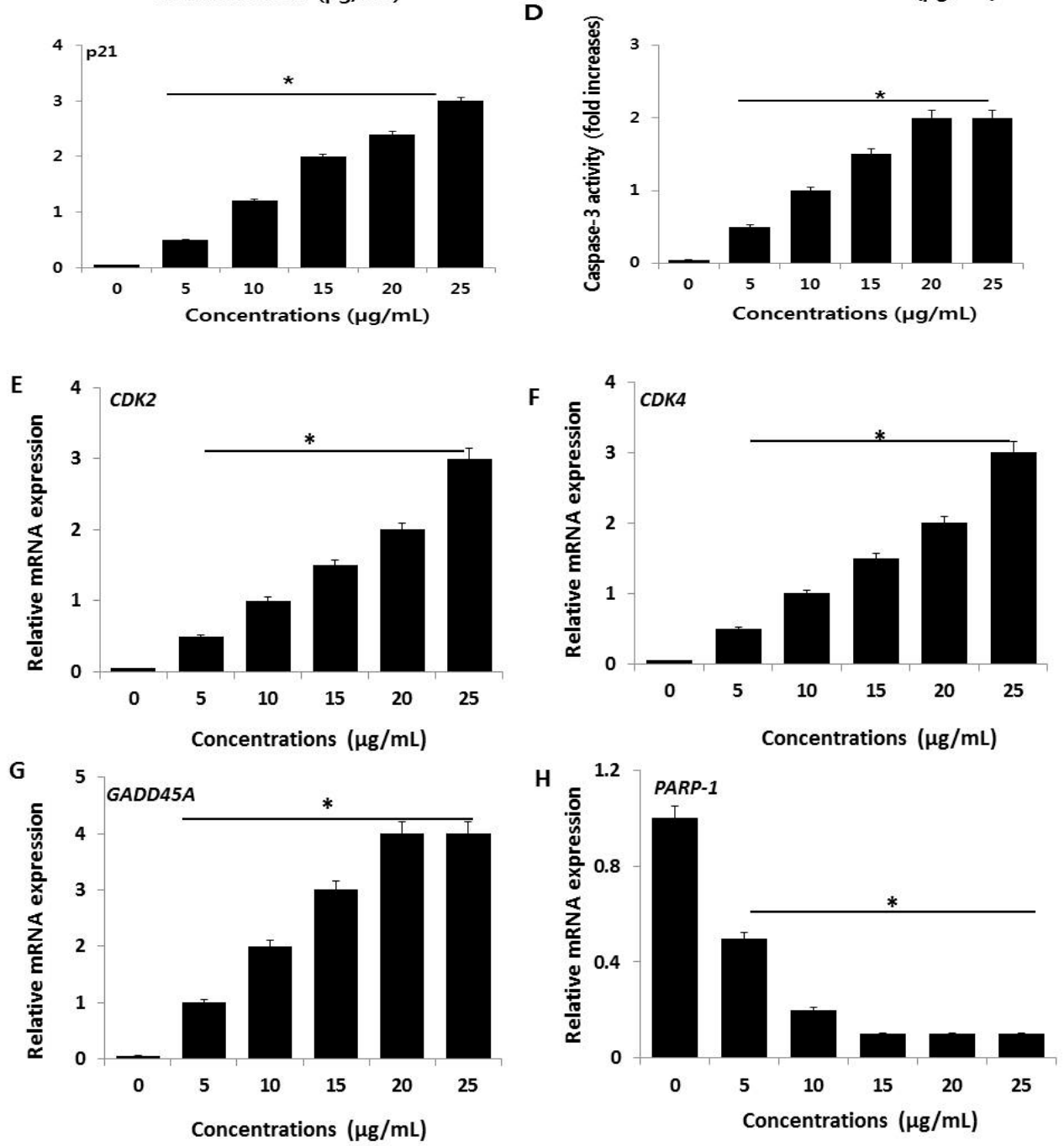

Figure 10. AgNPs induce DNA damage and increase expression of p53 and p21 genes in NIH3T3 cells. (A) 8-oxo-dG was measured after $24 \mathrm{~h}$ of exposure of NIH3T3 cells. AgNPs significantly increased oxidative DNA damage as evidenced by significant increases in 8-oxo-dG expressions. (B,C) Relative mRNA expression of $p 53$ and $p 21$ was analyzed using qRT-PCR in NIH3T3 cells treated with various concentrations of AgNPs for $24 \mathrm{~h}$. (D) Caspase-3 activity was measured in AgNP-treated NIH3T3 cells. The results are expressed as the mean \pm standard deviation of three separate experiments. (E-H) Relative mRNA expression of CDK2, CDK4, GADD45A and PARP-1 was analyzed using qRT-PCR in NIH3T3 cells treated with various concentrations of AgNPs for $24 \mathrm{~h}$. There was a significant difference in the ratio of AgNP-treated cells compared to untreated cells according to a Student's $t$-test $\left({ }^{*} p<0.05\right)$. 
To evaluate the effect of AgNPs on cell cycle arrests, the key regulators of G1/S transition, $C D K 2, C D K 4, G A D D 45 A$ and PARP-1 expression levels were analyzed by RT-PCR after $24 \mathrm{~h}$. $C D K 2, C D K 4$, and GADD45A were strongly up-regulated after AgNP treatment. PARP-1 was strongly down-regulated after AgNP treatment (Figure 10E-H). Furthermore, decreased expression of PARP-1 resulted increased caspase-3 activity, and increased p53 and p21 gene expression in NIH3T3 cells. Overall, the expression analysis confirmed that down-expression of PARP-1 suppressed cell proliferation and induced apoptosis of NIH3T3 cells through p53 signaling pathway and also it suggest a direct effect on cell cycle regulatory proteins and confirm prevention of G1/S phase progression.

\subsection{AgNPs Alter the Expression of Genes Involved in Apoptosis and Nucleosome Assembly}

To investigate the mechanism by which AgNPs elicit cell apoptosis in a dose-dependent manner, RNA-Seq was performed in normal cells and cells treated with a $50 \%$ inhibitory concentration of $\operatorname{AgNPs}(12 \mu \mathrm{g} / \mathrm{mL})$. We generated more than 20 million reads/sample from two biological replicas in each group. As illustrated in Figure 11A, 136 and 176 genes were down- and upregulated in AgNPs-treated cells, respectively. IGV tracks of HYAL1, HMOX1, HIST1H2BN, and HIST1H3A genes are visualized as representative genes in Figure 11B. We next investigated the biological processes impaired by AgNPs with differentially expressed genes. To that end, both up- and downregulated genes were used for gene ontology (GO) analysis. Interestingly, epigenetics-related biological processes including nucleosome assembly and DNA methylation were highly ranked in the analysis (Figure 12A). Dysregulation of epigenetics leads to cell apoptosis in normal and cancer cells [75,76]. Furthermore, accumulating evidence suggests that some NPs cause aberrant epigenetic changes, which in turn lead to detrimental effects to cell proliferation and survivor [77]. Next, we sought to determine biological processes with down- or upregulated genes. As shown in Figure 12B, positive regulation of angiogenesis and immune system process were identified as the most highly ranked biological processes with the downregulated genes. Enhanced expression of HMOX1, a gene associated with the positive regulation of angiogenesis, has been reported to modulate autophagy function and protect podocytes from apoptosis [78]. Also, elevated hyaluronidase 1 (HYAL1) expression affects endocytic vesicle trafficking and promotes aggressiveness of tumor cells [79]. Therefore, our RNA-Seq data suggest that the increased apoptosis of AgNPs-treated NIH3T3 cells was at least in part mediated by the repression of the genes.

A

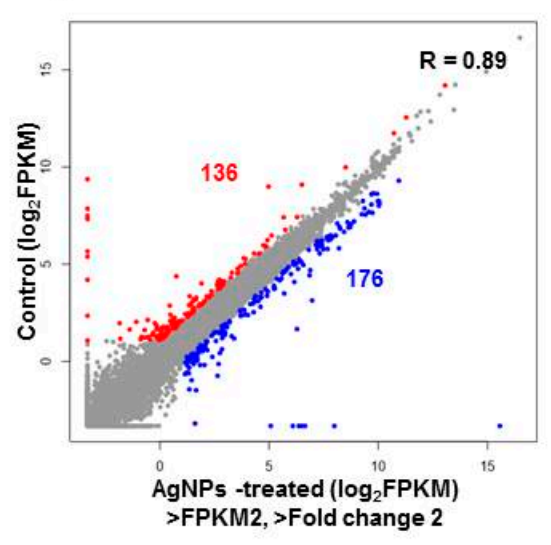

B

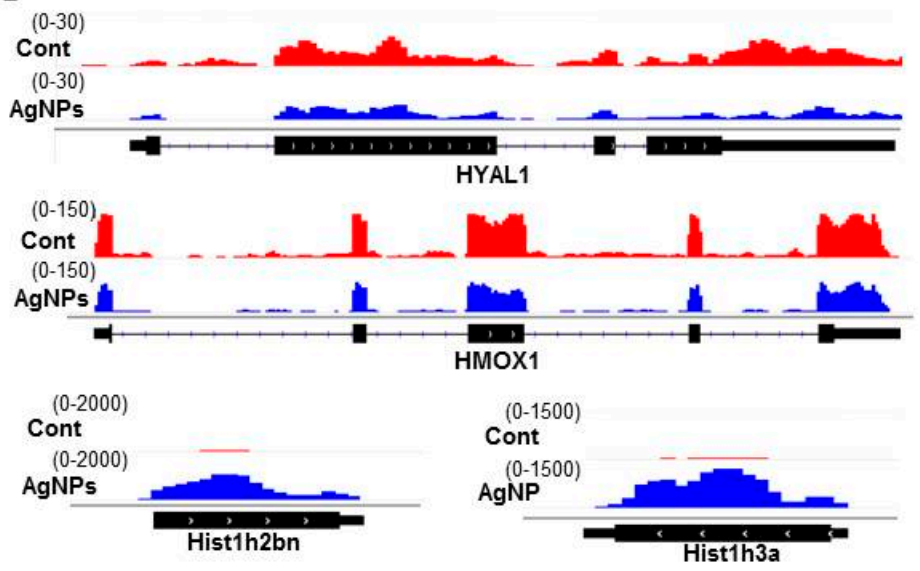

Figure 11. AgNPs administration changes gene expression. (A) A scatter plot showing genes up- or downregulated by AgNP treatment. Note that 136 and 176 genes were down- (red) and upregulated (blue), respectively. The $\log _{2}$ FPKM values were used for plotting. Cutoff value: FPKM $>2$ and fold change (FC) >2. (B) IGV tracks of representative up- (HIST1H2BN and HIST1H3A) and downregulated genes (HYAL1 and HMOX1). 
A

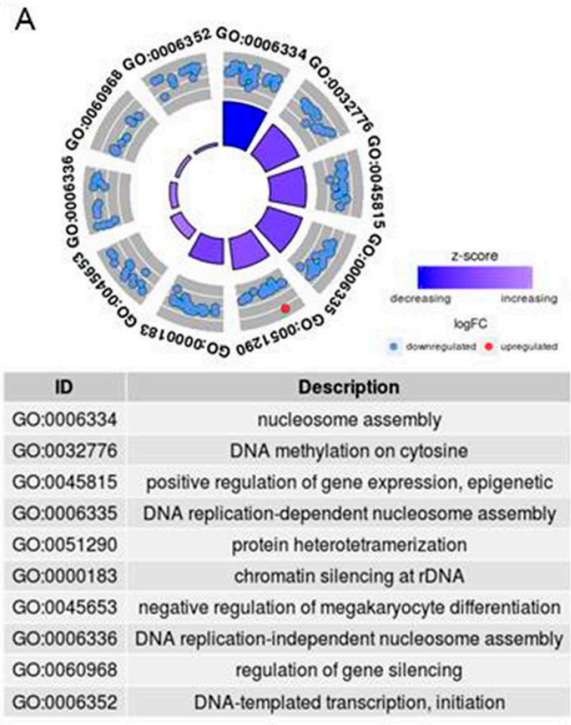

B

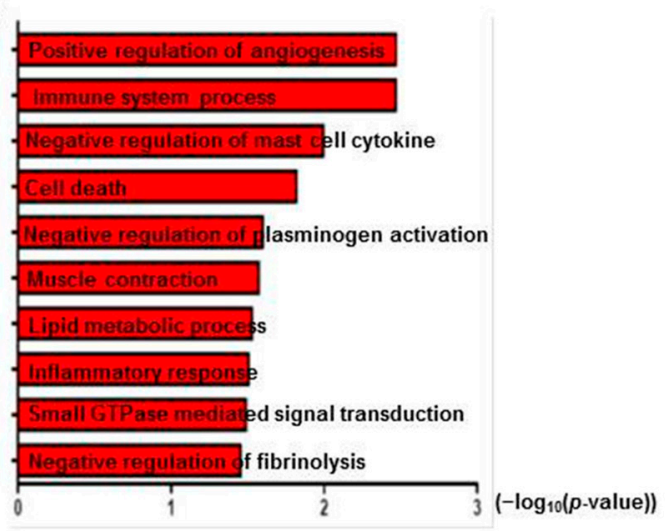

C

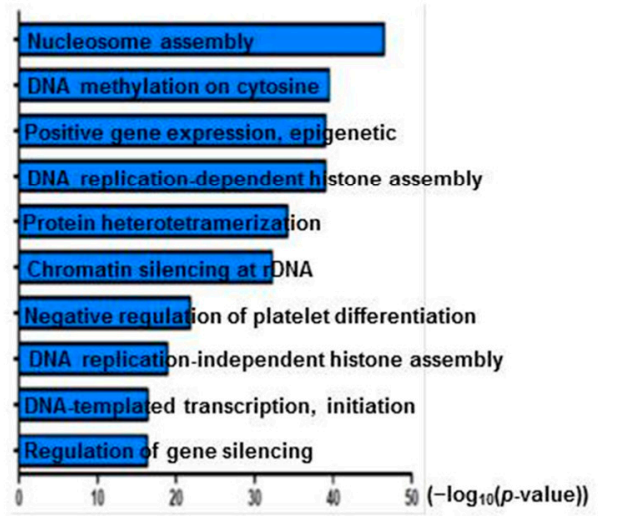

Figure 12. The altered gene expression is associated with apoptosis and nucleosome assembly. (A) gene ontology (GO) term analysis using both up- and downregulated genes together. (B) GO term analysis using downregulated genes only. (C) GO term analysis using upregulated genes only; $-\log _{10}$ ( $p$-value) is indicated on the x-axis.

Using all the differentially expressed genes (DEGs), we next determined biological pathways altered by AgNP exposure. As shown in Figure 13A, pathways related to cell death such as necroptosis (necrosis + apoptosis) and tumor necrosis factor (TNF) pathways were activated by the DEGs. Many GO terms related to epigenetics were identified in the upregulated genes. In particular, expressions of histone cluster genes were increased with AgNP treatment. Previous studies reported that many different NPs and nanomaterials affect aspects of epigenetic status, such as DNA methylation and histone modification [80,81]. AgNPs can induce phosphorylation of histone H3 at serine 10 (pH3S10) by Aurora kinase in a mitosis-independent manner [82]. Consistently, a subset of histones enriched in the necroptosis pathway was shown to be enhanced in their expressions upon AgNP treatment (Figure 13B). Therefore, our RNA-Seq data suggest that the increased apoptosis of AgNP-treated NIH3T3 cells was at least in part mediated by the change of gene transcription.

Many GO terms related to epigenetics were identified in the upregulated genes. In particular, expressions of histone cluster genes were increased with AgNP treatment. Previous studies reported that many different NPs and nanomaterials affect aspects of epigenetic status, such as DNA methylation and histone modification [80,81]. AgNPs can induce phosphorylation of histone $\mathrm{H} 3$ at serine 10 (pH3S10) by Aurora kinase in a mitosis-independent manner [82].

To the best of our knowledge, our study is the first demonstration that NPs can alter bulk histone gene expression. How the NPs cause epigenetic changes is still unclear, as is whether their effects on gene transcription are direct or indirect. Nevertheless, our genome-scale study suggests that apoptosis observed in AgNP-treated NIH3T3 cells is mediated by the repression of genes required for cell survival and because of the aberrant enhancement of the components of nucleosome assembly. 


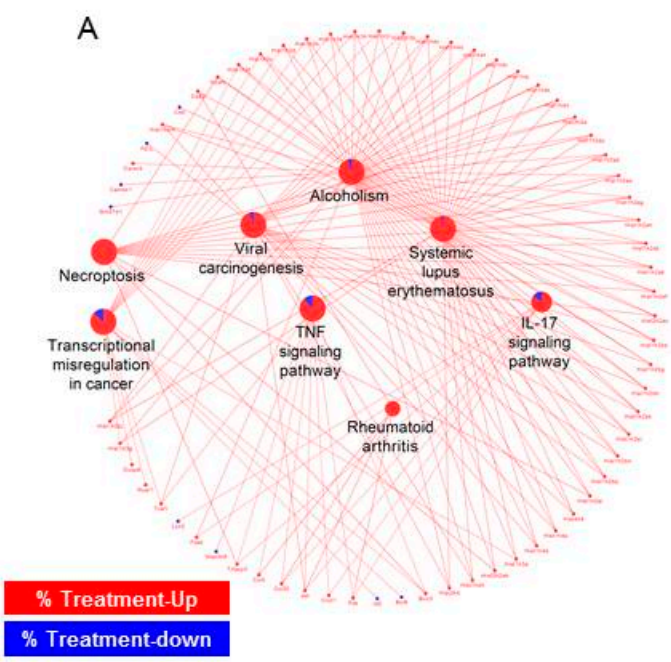

B

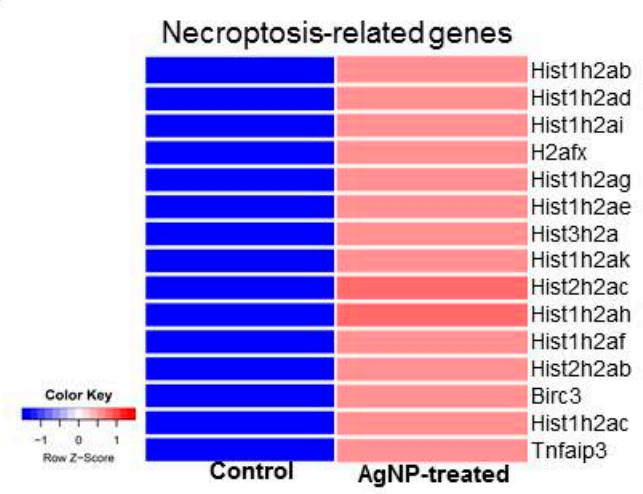

Figure 13. Biological pathways associated cell death are activated by AgNP treatment. (A) Network analysis showing aberrantly activated pathways in AgNP-treated NIH3T3 cells. Red and blue in the pie chart of pathway represent the ratio of up- and downregulated genes, respectively. (B) Heatmap showing expression level of genes classified in necroptosis pathway.

\section{Materials and Methods}

\subsection{Synthesis and Characterization of AgNPs}

Synthesis of AgNPs was carried with myricetin dissolved in dimethyl sulfoxide (DMSO; $1 \mathrm{mg} / \mathrm{mL}$ ). AgNPs were synthesized by incubating $1 \mathrm{mg}$ myricetin in $100 \mathrm{~mL}$ of water containing 1 $\mathrm{mM} \mathrm{AgNO} 3$ at $37^{\circ} \mathrm{C}$ for $1 \mathrm{~h} \mathrm{[83].}$

\subsection{Cell Viability and BrdU Cell Proliferation Assay}

Cell viability was measured using Cell Counting Kit-8 (CCK-8; CK04-01, Dojindo Laboratories, Kumamoto, Japan). Cell proliferation was determined according to manufacturer's instructions (Roche, Basel, Switzerland). Cells were incubated with various concentrations of AgNPs for $24 \mathrm{~h}$ with the BrdU labeling solution added $2 \mathrm{~h}$ before the end of the incubation.

\subsection{Membrane Integrity}

The membrane integrity of NIH3T3 fibroblasts was evaluated using an LDH Cytotoxicity Detection Kit (Sigma-Aldrich, St. Louis, MO, USA). Briefly, cells were exposed to various concentrations of AgNPs for $24 \mathrm{~h}$.

\subsection{Determination of Intracellular ROS}

NIH3T3 fibroblasts cells were treated with AgNPs for $24 \mathrm{~h}$. ROS was measured as previously described [47] based on the intracellular peroxide-dependent oxidation of $2^{\prime}, 7^{\prime}$-dichlorodihydrofluorescein diacetate (DCFH-DA; Molecular Probes, Eugene, OR, USA) to form the fluorescent compound $2^{\prime}, 7^{\prime}$-dichlorofluorescein (DCF).

\subsection{Measurement of Oxidative and Antioxidant Markers}

The oxidative stress markers MDA, GSH, and SOD were assayed according to the manufacturer's instructions (Sigma-Aldrich, St. Louis, MO, USA).

\subsection{JC-1 Assay and Measurement of ATP}

NIH3T3 fibroblasts were treated with AgNPs for $24 \mathrm{~h}$. The change in MMP was determined using the cationic fluorescent dye JC-1 (Molecular Probes). The ATP level was measured in NIH3T3 cells 
according to the manufacturer's instructions (Catalog Number MAK135, Sigma-Aldrich). The cells were exposed to various concentrations of AgNPs for $24 \mathrm{~h}$ and the level of ATP was measured.

\subsection{Measurement of 8-oxo-dG}

8-oxo-dG was determined as described previously [37] and also according to manufacturer's instructions (Trevigen, Gaithersburg, MD, USA).

\subsection{Measurement of Caspase 3 Activity}

The caspase-3 activity was measured according to manufacturer instructions. The cells were treated with AgNPs for $24 \mathrm{~h}$, and then the activity of caspase-3/9 was measured in the cancer cells using a kit from (Sigma-Aldrich, St. Louis, MO, USA). The calorimetric assay was based on the hydrolysis of the caspase-3 substrate by caspase-3, resulting in the release of the p-nitroaniline (pNA) moiety. The concentration of pNA released from the substrate was calculated from the absorbance values at $405 \mathrm{~nm}$.

\subsection{Reverse Transcription-Quantitative Polymerase Chain Reaction (RT-qPCR)}

Total RNA was extracted from the cells treated with various concentrations of AgNPs for $24 \mathrm{~h}$ using the PicoPure RNA isolation kit (Arcturus Bioscience, Mountain View, CA, USA). Samples were prepared according to the manufacturer's instructions. Real-time RT-qPCR was conducted using a Vill7 (Applied Biosystems, Foster City, CA, USA) and SYBR Green as the double-stranded DNA-specific fluorescent dye (Applied Biosystems). Target gene expression levels were normalized to the expression of glyceraldehyde-3-phosphate dehydrogenase (GAPDH) expression, which was unaffected by treatment. The real-time qRT-PCR primer sets are shown in Table 2.

Table 2. List of primers used for quantitative real-time polymerase chain reaction for analysis of apoptotic and cell cycle arrest gene expression.

\begin{tabular}{cl}
\hline Gene & Primer \\
\hline \multirow{2}{*}{ 53 } & $\begin{array}{l}\text { F: AGAGACCGTACAGAAGA } \\
\text { R: CTGTAGCATGGGATCCTTT }\end{array}$ \\
\hline \multirow{2}{*}{ p21 } & $\begin{array}{l}\text { F: GTTGCTGTCCGGACTACCG } \\
\text { R: AAAAACAATGCCACCACTCC }\end{array}$ \\
\hline \multirow{2}{*}{ PARP-1 } & F: CTCCATCCTGGCCTCGCTGT \\
& R: GCTGTCACCTT CACCGTTCC \\
\hline \multirow{2}{*}{ CDK2 } & F: GCTAGCAGACTTTGGACTAGCCAG \\
& R: AGCTCGGTACCACAGGGTCA \\
\hline \multirow{2}{*}{ CDK4 } & F: CTGGTGTTTGAGCATGTAGACC \\
& R: AAACTGGCGCATCAGATCCTT \\
\hline \multirow{2}{*}{ GAPP45A } & F: TGCTCAGCAAAGCCCTGAGT \\
& R: GCTTGGCCGCTTCGTACA \\
\hline \multirow{2}{*}{ GAPDH } & F: TGCACCACCAACTGCTTAGC \\
& R: GGCATGGACTGTGGTCATGAG \\
\hline
\end{tabular}

\subsection{RNA-Seq and Downstream Bioinformatics Analysis}

Total RNA was obtained from control and AgNs-treated cells using an RNeasy kit (Qiagen, Valencia, CA, USA), and their concentration and quality for library preparation was determined using Bioanalyzer RNA chip (Agilent Technologies, Santa Clara, CA, USA). RNAs with an RNA integration number $>7$ were used for library preparation using TruSeq stranded total RNA sample preparation kit (Illumina, San Diego, CA, USA). Briefly, the total RNAs were subjected to cDNA synthesis, fragmentation, adaptor ligation, and PCR amplification. Sequencing was performed on 
the NextSeq500 platform (Illumina). After sequencing, the sequencing reads were further processed with determination of quality and trimming the adaptors using the FastQC tool. The clean reads were mapped to mouse $\mathrm{mm} 9$ genome using the STAR package. The fragments per kilobase million (FPKM) and differentially expressed genes (DEGs) were obtained using the following Cufflink (version 2.2.1, Seattle, WA, USA) option: -library-type $=$ fr-second strand. DEGs was determined at FPKM $>2$ and fold change (FC) $>2$. DAVID (version 6.8, Frederick, MD, USA) tool was used to determine enrichment of biological processes. R package (version 3.3.2, Vienna, Austria) and GO plot package (version 1.0.2, Madrid, Spain) were used for generation of scatter plot and GO terms, respectively. Biological pathways were determined using ClueGO tool plugged in Cytoscape (version 3.6.1, La Jolla, CA, USA).

\subsection{Statistical Analyses}

All assays were conducted in triplicate, and each experiment was repeated at least three times. The results represent the means of at least three independent experiments (mean \pm standard deviation). Student's $t$-test or one-way analysis of variance, followed by Tukey's test for multiple comparisons were calculated, using GraphPad Prism software (GraphPad Software, San Diego, CA, USA). Differences were considered significant at $p<0.05$.

\section{Conclusions}

The increasing use of AgNPs in consumer, industrial, and biomedical products has prompted global concern regarding their toxicity and their impact to biological systems. We prepared AgNPs using the flavonoid myricetin. The synthesized AgNPs were characterized by various analytical techniques. The prepared AgNPs had an average size of $55 \mathrm{~nm}$ and were uniformly spherical in shape. Next, we examined the effects of biogenic AgNPs on NIH3T3 cells to decipher the molecular mechanism of nanotoxicity and biochemical pathways involved. AgNPs induced the loss of cell viability and proliferation via increased leakage of $\mathrm{LDH}$, the generation of ROS, increased MDA levels and decreased levels of antioxidants. AgNPs caused mitochondrial dysfunction through alteration of membrane permeability and generation of ATP. The induction of apoptosis by DNA damage was apparent by the increased level of 8-oxodG and increased expressions of p53 and p21. The AgNP-induced death of NIH3T3 cells suggests that NP-induced oxidative stress could have an important influence on NIH3T3 cell survival. AgNP-induced oxidative stress can eventually cause genotoxicity by DNA adducts, DNA breaks, and increased 8-oxoguanine level. RNA-Seq analysis suggested that AgNPs alter epigenetics-related biological processes including nucleosome assembly and DNA methylation. AgNPs could also influence the cell cycle, and induce DNA hypermethylation via the p53 or p21 pathway, which may have an effect on epigenomic level. Our genome-scale study suggested that the apoptosis observed in AgNPs-treated NIH3T3 cells is mediated by the repression of genes required for cell survival and by the aberrant enhancement of components of nucleosome assembly, with the resulting induction of apoptosis. This combination study of cellular assays and RNA-Seq is the first report demonstrating that AgNPs can alter cellular responses and bulk histone gene expression in MEFs, which provides an in vitro model system to study various biological events as well as disease states.

Author Contributions: S.G. came up with the idea and participated in the design, performed synthesis and characterization of nanomaterials, cellular assays and wrote the manuscript. M.Q. prepared samples for RNA-Seq analysis and J.-H.K. analyzed the data along with monitored data. K.H., H.Y. and C.P. (Chanhyeok Park), D.Y.C., C.P. (Chankyu Park) and H.S. performed RNA-Seq and downstream bioinformatics analysis. All authors read and approved the final manuscript.

Funding: S.G. is supported by the KU-Research Professor Program of Konkuk University. This research was funded by National Research Foundation of Korea (Science Research Center, 2015R1A5A1009701).

Acknowledgments: This study is supported by the KU-Research Professor Program of Konkuk University. This work is supported by a grant from the Science Research Center (2015R1A5A1009701) of the National Research Foundation of Korea. Authors are indebted to members in J.H.K. and K.H. labs for helpful comments and discussion. 
Conflicts of Interest: The authors declare no conflict of interest.

\section{References}

1. Chen, X.; Schluesener, H.J. Nanosilver: A nanoproduct in medical application. Toxicol. Lett. 2008, 176, 1-12. [CrossRef] [PubMed]

2. Oberdörster, G.; Oberdörster, E.; Oberdörster, J. Nanotoxicology: An emerging discipline evolving from studies of ultrafine particles. Environ. Health Perspect. 2005, 113, 823-839. [CrossRef] [PubMed]

3. Lewinski, N.; Colvin, V.; Drezek, R. Cytotoxicity of nanoparticles. Small 2008, 4, 26-49. [CrossRef] [PubMed]

4. Lee, Y.H.; Cheng, F.Y.; Chiu, H.W.; Tsai, J.C.; Fang, C.Y.; Chen, C.W.; Wang, Y.J. Cytotoxicity, oxidative stress, apoptosis and the autophagic effects of silver nanoparticles in mouse embryonic fibroblasts. Biomaterials 2014, 35, 4706-4715. [CrossRef] [PubMed]

5. Zhang, B.; Sai Lung, P.; Zhao, S.; Chu, Z.; Chrzanowski, W.; Li, Q. Shape dependent cytotoxicity of PLGA-PEG nanoparticles on human cells. Sci. Rep. 2017, 7, 7315. [CrossRef] [PubMed]

6. Salatin, S.; Yari Khosroushahi, A. Overviews on the cellular uptake mechanism of polysaccharide colloidal nanoparticles. J. Cell Mol. Med. 2017, 21, 1668-1686. [CrossRef] [PubMed]

7. Lee, J.H.; Kim, Y.S.; Song, K.S.; Ryu, H.R.; Sung, J.H.; Park, J.D.; Park, H.M.; Song, N.W.; Shin, B.S.; Marshak, D.; et al. Biopersistence of silver nanoparticles in tissues from Sprague-Dawley rats. Part. Fibre Toxicol. 2013, 10, 36. [CrossRef] [PubMed]

8. Finkel, T.; Holbrook, N.J. Oxidants, oxidative stress and the biology of ageing. Nature 2000, 408, $239-247$. [CrossRef] [PubMed]

9. Gurunathan, S.; Han, J.W.; Eppakayala, V.; Jeyaraj, M.; Kim, J.H. Cytotoxicity of biologically synthesized silver nanoparticles in MDA-MB-231 human breast cancer cells. BioMed Res. Int. 2013, 2013, 535796. [CrossRef] [PubMed]

10. Gurunathan, S.; Jeong, J.K.; Han, J.W.; Zhang, X.F.; Park, J.H.; Kim, J.H. Multidimensional effects of biologically synthesized silver nanoparticles in Helicobacter pylori, Helicobacter felis, and human lung (L132) and lung carcinoma A549 cells. Nanoscale Res. Lett. 2015, 10, 35. [CrossRef] [PubMed]

11. Han, J.W.; Gurunathan, S.; Jeong, J.K.; Choi, Y.J.; Kwon, D.N.; Park, J.K.; Kim, J.H. Oxidative stress mediated cytotoxicity of biologically synthesized silver nanoparticles in human lung epithelial adenocarcinoma cell line. Nanoscale Res. Lett. 2014, 9, 459. [CrossRef] [PubMed]

12. Braydich-Stolle, L.; Hussain, S.; Schlager, J.J.; Hofmann, M.C. In vitro cytotoxicity of nanoparticles in mammalian germline stem cells. Toxicol. Sci. 2005, 88, 412-419. [CrossRef] [PubMed]

13. Hsin, Y.H.; Chen, C.F.; Huang, S.; Shih, T.S.; Lai, P.S.; Chueh, P.J. The apoptotic effect of nanosilver is mediated by a ROS- and JNK-dependent mechanism involving the mitochondrial pathway in NIH3T3 cells. Toxicol. Lett. 2008, 179, 130-139. [CrossRef] [PubMed]

14. AshaRani, P.V.; Low Kah Mun, G.; Hande, M.P.; Valiyaveettil, S. Cytotoxicity and Genotoxicity of Silver Nanoparticles in Human Cells. ACS Nano 2009, 3, 279-290. [CrossRef] [PubMed]

15. Jeong, J.K.; Gurunathan, S.; Kang, M.H.; Han, J.W.; Das, J.; Choi, Y.J.; Kwon, D.N.; Cho, S.G.; Park, C.; Seo, H.G.; et al. Hypoxia-mediated autophagic flux inhibits silver nanoparticle-triggered apoptosis in human lung cancer cells. Sci. Rep. 2016, 6, 21688. [CrossRef] [PubMed]

16. Park, J.H.; Gurunathan, S.; Choi, Y.J.; Han, J.W.; Song, H.; Kim, J.H. Silver nanoparticles suppresses brain-derived neurotrophic factor-induced cell survival in the human neuroblastoma cell line SH-SY5Y. J. Ind. Eng. Chem. 2017, 47, 62-73. [CrossRef]

17. Singhal, P.K.; Sassi, S.; Lan, L.; Au, P.; Halvorsen, S.C.; Fukumura, D.; Jain, R.K.; Seed, B. Mouse embryonic fibroblasts exhibit extensive developmental and phenotypic diversity. Proc. Natl. Acad. Sci. USA 2016, 113, 122-127. [CrossRef] [PubMed]

18. Mytych, J.; Zebrowski, J.; Lewinska, A.; Wnuk, M. Prolonged effects of silver nanoparticles on p53/p21 pathway-mediated proliferation, DNA damage response, and methylation parameters in HT22 hippocampal neuronal cells. Mol. Neurobiol. 2017, 54, 1285-1300. [CrossRef] [PubMed]

19. Siu, H.; Zhu, Y.; Jin, L.; Xiong, M. Implication of next-generation sequencing on association studies. BMC Genom. 2011, 12, 322. [CrossRef] [PubMed] 
20. Feliu, N.; Kohonen, P.; Ji, J.; Zhang, Y.; Karlsson, H.L.; Palmberg, L.; Nyström, A.; Fadeel, B. Next-generation sequencing reveals low-dose effects of cationic dendrimers in primary human bronchial epithelial cells. ACS Nano 2015, 9, 146-163. [CrossRef] [PubMed]

21. Liu, Y.; Guo, Y.; Ma, C.; Zhang, D.; Wang, C.; Yang, Q. Transcriptome analysis of maize resistance to Fusarium graminearum. BMC Genom. 2016, 17, 477. [CrossRef]

22. Sun, Q.L.; Zhao, C.P.; Wang, T.Y.; Hao, X.B.; Wang, X.Y.; Zhang, X.; Li, Y.C. Expression profile analysis of long non-coding RNA associated with vincristine resistance in colon cancer cells by next-generation sequencing. Gene 2015, 572, 79-86. [CrossRef] [PubMed]

23. Wang, Z.; Gerstein, M.; Snyder, M. RNA-Seq: A revolutionary tool for transcriptomics. Nat. Rev. Genet. 2009, 10, 57-63. [CrossRef] [PubMed]

24. Lin, H.N.; Hsu, W.L.; Berger, B. DART: A fast and accurate RNA-seq mapper with a partitioning strategy. Bioinformatics 2018, 34, 190-197. [CrossRef] [PubMed]

25. Hawkins, T.; Chitale, M.; Kihara, D. Functional enrichment analyses and construction of functional similarity networks with high confidence function prediction by PFP. BMC Bioinform. 2010, 11, 265. [CrossRef] [PubMed]

26. Maher, C.A.; Palanisamy, N.; Brenner, J.C.; Cao, X.; Kalyana-Sundaram, S.; Luo, S.; Khrebtukova, I.; Barrette, T.R.; Grasso, C.; Yu, J.; et al. Chimeric transcript discovery by paired-end transcriptome sequencing. Proc. Natl. Acad. Sci. USA 2009, 106, 12353-12358. [CrossRef] [PubMed]

27. Costa, B.M.; Smith, J.S.; Chen, Y.; Chen, J.; Phillips, H.S.; Aldape, K.D.; Zardo, G.; Nigro, J.; James, C.D.; Fridlyand, J.; et al. Reversing HOXA9 oncogene activation by PI3K inhibition: Epigenetic mechanism and prognostic significance in human glioblastoma. Cancer Res. 2010, 70, 453-462. [CrossRef] [PubMed]

28. Vigneshwaran, N.; Ashtaputre, N.M.; Varadarajan, P.V.; Nachane, R.P.; Paralikar, K.M.; Balasubramanya, R.H. Biological synthesis of silver nanoparticles using the fungus Aspergillus flavus. Mater. Lett. 2007, 61, 1413-1418. [CrossRef]

29. Jain, S.; Mehata, M.S. Medicinal Plant Leaf Extract and Pure Flavonoid Mediated Green Synthesis of Silver Nanoparticles and their Enhanced Antibacterial Property. Sci. Rep. 2017, 7, 15867. [CrossRef] [PubMed]

30. Gurunathan, S.; Lee, K.J.; Kalishwaralal, K.; Sheikpranbabu, S.; Vaidyanathan, R.; Eom, S.H. Antiangiogenic properties of silver nanoparticles. Biomaterials 2009, 30, 6341-6350. [CrossRef] [PubMed]

31. Kalishwaralal, K.; BarathManiKanth, S.; Pandian, S.R.K.; Deepak, V.; Gurunathan, S. Silver nanoparticles impede the biofilm formation by Pseudomonas aeruginosa and Staphylococcus epidermidis. Colloids Surf. B Biointerfaces 2010, 79, 340-344. [CrossRef] [PubMed]

32. Gurunathan, S. Rapid biological synthesis of silver nanoparticles and their enhanced antibacterial effects against Escherichia fergusonii and Streptococcus mutans. Arab. J. Chem. 2014. [CrossRef]

33. Fissan, H.; Ristig, S.; Kaminski, H.; Asbach, C.; Epple, M. Comparison of different characterization methods for nanoparticle dispersions before and after aerosolization. Anal. Methods 2014, 6, 7324. [CrossRef]

34. Sahu, N.; Soni, D.; Chandrashekhar, B.; Satpute, D.B.; Saravanadevi, S.; Sarangi, B.K.; Pandey, R.A. Synthesis of silver nanoparticles using flavonoids: Hesperidin, naringin and diosmin, and their antibacterial effects and cytotoxicity. Int. Nano Lett. 2016, 6, 173-181. [CrossRef]

35. Prathna, T.C.; Chandrasekaran, N.; Raichur, A.M.; Mukherjee, A. Biomimetic synthesis of silver nanoparticles by Citrus limon (lemon) aqueous extract and theoretical prediction of particle size. Colloids Surf. B Biointerfaces 2011, 82, 152-159. [CrossRef] [PubMed]

36. Gurunathan, S.; Han, J.W.; Park, J.H.; Kim, E.; Choi, Y.J.; Kwon, D.N.; Kim, J.H. Reduced graphene oxide-silver nanoparticle nanocomposite: A potential anticancer nanotherapy. Int. J. Nanomedicine 2015, 10, 6257-6276. [CrossRef] [PubMed]

37. Liu, F.; Mahmood, M.; Xu, Y.; Watanabe, F.; Biris, A.S.; Hansen, D.K.; Inselman, A.; Casciano, D.; Patterson, T.A.; Paule, M.G.; et al. Effects of silver nanoparticles on human and rat embryonic neural stem cells. Front. Neurosci. 2015, 9, 115. [CrossRef] [PubMed]

38. Yuan, Y.G.; Wang, Y.H.; Xing, H.H.; Gurunathan, S. Quercetin-mediated synthesis of graphene oxide-silver nanoparticle nanocomposites: A suitable alternative nanotherapy for neuroblastoma. Int. J. Nanomed. 2017, 12, 5819-5839. [CrossRef] [PubMed]

39. Dalle-Donne, I.; Rossi, R.; Giustarini, D.; Colombo, R.; Milzani, A. S-glutathionylation in protein redox regulation. Free Radic. Biol. Med. 2007, 43, 883-898. [CrossRef] [PubMed] 
40. Roda, E.; Barni, S.; Milzani, A.; Dalle-Donne, I.; Colombo, G.; Coccini, T. Single silver nanoparticle instillation induced early and persisting moderate cortical damage in rat kidneys. Int. J. Mol. Sci. 2017, 18, 2115. [CrossRef] [PubMed]

41. Martindale, J.L.; Holbrook, N.J. Cellular response to oxidative stress: Signaling for suicide and survival. J. Cell Physiol. 2002, 192, 1-15. [CrossRef] [PubMed]

42. Reidy, B.; Haase, A.; Luch, A.; Dawson, K.A.; Lynch, I. Mechanisms of silver nanoparticle release, transformation and toxicity: A critical review of current knowledge and recommendations for future studies and applications. Materials 2013, 6, 2295-2350. [CrossRef] [PubMed]

43. Haase, A.; Rott, S.; Mantion, A.; Graf, P.; Plendl, J.; Thünemann, A.F.; Meier, W.P.; Taubert, A.; Luch, A.; Reiser, G. Effects of silver nanoparticles on primary mixed neural cell cultures: Uptake, oxidative stress and acute calcium responses. Toxicol. Sci. 2012, 126, 457-468. [CrossRef] [PubMed]

44. Haase, A.; Mantion, A.; Graf, P.; Plendl, J.; Thuenemann, A.F.; Meier, W.; Taubert, A.; Luch, A. A novel type of silver nanoparticles and their advantages in toxicity testing in cell culture systems. Arch. Toxicol. 2012, 86, 1089-1098. [CrossRef] [PubMed]

45. Srikanth, K.; Sundar, L.S.; Pereira, E.; Duarte, A.C. Graphene oxide induces cytotoxicity and oxidative stress in bluegill sunfish cells. J. Appl. Toxicol. 2018, 38, 504-513. [CrossRef] [PubMed]

46. Gliga, A.R.; di Bucchianico, S.; Lindvall, J.; Fadeel, B.; Karlsson, H.L. RNA-sequencing reveals long-term effects of silver nanoparticles on human lung cells. Sci. Rep. 2018, 8, 6668. [CrossRef] [PubMed]

47. Gurunathan, S.; Park, J.H.; Han, J.W.; Kim, J.H. Comparative assessment of the apoptotic potential of silver nanoparticles synthesized by Bacillus tequilensis and Calocybe indica in MDA-MB-231 human breast cancer cells: Targeting p53 for anticancer therapy. Int. J. Nanomed. 2015, 10, 4203. [CrossRef] [PubMed]

48. Mei, N.; Zhang, Y.; Chen, Y.; Guo, X.; Ding, W.; Ali, S.F.; Biris, A.S.; Rice, P.; Moore, M.M.; Chen, T. Silver nanoparticle-induced mutations and oxidative stress in mouse lymphoma cells. Environ. Mol. Mutagen. 2012, 53, 409-419. [CrossRef] [PubMed]

49. Rahman, M.F.; Wang, J.; Patterson, T.A.; Saini, U.T.; Robinson, B.L.; Newport, G.D.; Murdock, R.C.; Schlager, J.J.; Hussain, S.M.; Ali, S.F. Expression of genes related to oxidative stress in the mouse brain after exposure to silver-25 nanoparticles. Toxicol. Lett. 2009, 187, 15-21. [CrossRef] [PubMed]

50. Birben, E.; Sahiner, U.M.; Sackesen, C.; Erzurum, S.; Kalayci, O. Oxidative stress and antioxidant defense. World Allergy Organ. J. 2012, 5, 9-19. [CrossRef] [PubMed]

51. Hussain, S.M.; Hess, K.L.; Gearhart, J.M.; Geiss, K.T.; Schlager, J.J. In vitro toxicity of nanoparticles in BRL 3A rat liver cells. Toxicol. In Vitro 2005, 19, 975-983. [CrossRef] [PubMed]

52. Arora, M.; Kumar, A.; Kaundal, R.K.; Sharma, S.S. Amelioration of neurological and biochemical deficits by peroxynitrite decomposition catalysts in experimental diabetic neuropathy. Eur. J. Pharmacol. 2008, 596, 77-83. [CrossRef] [PubMed]

53. Piao, M.J.; Kang, K.A.; Lee, I.K.; Kim, H.S.; Kim, S.; Choi, J.Y.; Choi, J.; Hyun, J.W. Silver nanoparticles induce oxidative cell damage in human liver cells through inhibition of reduced glutathione and induction of mitochondria-involved apoptosis. Toxicol. Lett. 2011, 201, 92-100. [CrossRef] [PubMed]

54. Awasthi, K.K.; Awasthi, A.; Verma, R.; Soni, I.; Awasthi, K.; John, P.J. Silver nanoparticles and carbon nanotubes induced DNA damage in mice evaluated by single cell gel electrophoresis. Macromol. Symp. 2015, 357, 210-217. [CrossRef]

55. Yuan, Y.G.; Peng, Q.L.; Gurunathan, S. Combination of palladium nanoparticles and tubastatin-A potentiates apoptosis in human breast cancer cells: A novel therapeutic approach for cancer. Int. J. Nanomed. 2017, 12, 6503-6520. [CrossRef] [PubMed]

56. Sakamuru, S.; Attene-Ramos, M.S.; Xia, M. Mitochondrial membrane potential assay. Methods Mol. Biol. 2016, 1473, 17-22. [CrossRef] [PubMed]

57. Sun, C.; Yin, N.; Wen, R.; Liu, W.; Jia, Y.; Hu, L.; Zhou, Q.; Jiang, G. Silver nanoparticles induced neurotoxicity through oxidative stress in rat cerebral astrocytes is distinct from the effects of silver ions. Neurotoxicology 2016, 52, 210-221. [CrossRef] [PubMed]

58. Aueviriyavit, S.; Phummiratch, D.; Maniratanachote, R. Mechanistic study on the biological effects of silver and gold nanoparticles in Caco-2 cells-Induction of the Nrf2/HO-1 pathway by high concentrations of silver nanoparticles. Toxicol. Lett. 2014, 224, 73-83. [CrossRef] [PubMed] 
59. Zhang, R.; Piao, M.J.; Kim, K.C.; Kim, A.D.; Choi, J.Y.; Choi, J.; Hyun, J.W. Endoplasmic reticulum stress signaling is involved in silver nanoparticles-induced apoptosis. Int. J. Biochem. Cell Biol. 2012, 44, 224-232. [CrossRef] [PubMed]

60. Orlowski, P.; Krzyzowska, M.; Zdanowski, R.; Winnicka, A.; Nowakowska, J.; Stankiewicz, W.; Tomaszewska, E.; Celichowski, G.; Grobelny, J. Assessment of in vitro cellular responses of monocytes and keratinocytes to tannic acid modified silver nanoparticles. Toxicol. In Vitro 2013, 27, 1798-1808. [CrossRef] [PubMed]

61. Smeitink, J.A.; Zeviani, M.; Turnbull, D.M.; Jacobs, H.T. Mitochondrial medicine: A metabolic perspective on the pathology of oxidative phosphorylation disorders. Cell Metab. 2006, 3, 9-13. [CrossRef] [PubMed]

62. Martínez-Reyes, I.; Diebold, L.P.; Kong, H.; Schieber, M.; Huang, H.; Hensley, C.T.; Mehta, M.M.; Wang, T.; Santos, J.H.; Woychik, R.; et al. TCA cycle and mitochondrial membrane potential are necessary for diverse biological functions. Mol. Cell 2016, 61, 199-209. [CrossRef] [PubMed]

63. Bohovych, I.; Khalimonchuk, O. Sending out an SOS: Mitochondria as a signaling hub. Front. Cell Dev. Biol. 2016, 4, 109. [CrossRef] [PubMed]

64. Neustadt, J.; Pieczenik, S.R. Medication-induced mitochondrial damage and disease. Mol. Nutr. Food Res. 2008, 52, 780-788. [CrossRef] [PubMed]

65. Maurer, L.L.; Meyer, J.N. A systematic review of evidence for silver nanoparticle-induced mitochondrial toxicity. Environ. Sci. Nano 2016, 3, 311-322. [CrossRef]

66. Geromel, V.; Kadhom, N.; Cebalos-Picot, I.; Ouari, O.; Polidori, A.; Munnich, A.; Rötig, A.; Rustin, P. Superoxide-induced massive apoptosis in cultured skin fibroblasts harboring the neurogenic ataxia retinitis pigmentosa (NARP) mutation in the ATPase-6 gene of the mitochondrial DNA. Hum. Mol. Genet. 2001, 10, 1221-1228. [CrossRef] [PubMed]

67. Valavanidis, A.; Vlachogianni, T.; Fiotakis, C. 8-hydroxy-2'-deoxyguanosine (8-OHdG): A critical biomarker of oxidative stress and carcinogenesis. J. Environ. Sci. Health Part C 2009, 27, 120-139. [CrossRef] [PubMed]

68. Sriram, M.I.; Kanth, S.B.M.; Kalishwaralal, K.; Gurunathan, S. Antitumor activity of silver nanoparticles in Dalton's lymphoma ascites tumor model. Int. J. Nanomed. 2010, 5, 753-762. [CrossRef]

69. Foldbjerg, R.; Dang, D.A.; Autrup, H. Cytotoxicity and genotoxicity of silver nanoparticles in the human lung cancer cell line, A549. Arch. Toxicol. 2011, 85, 743-750. [CrossRef] [PubMed]

70. Hackenberg, S.; Scherzed, A.; Kessler, M.; Hummel, S.; Technau, A.; Froelich, K.; Ginzkey, C.; Koehler, C.; Hagen, R.; Kleinsasser, N. Silver nanoparticles: Evaluation of DNA damage, toxicity and functional impairment in human mesenchymal stem cells. Toxicol. Lett. 2011, 201, 27-33. [CrossRef] [PubMed]

71. Zhang, X.F.; Huang, F.H.; Zhang, G.L.; Bai, D.P.; Massimo, D.F.; Huang, Y.F.; Gurunathan, S. Novel biomolecule lycopene-reduced graphene oxide-silver nanoparticle enhances apoptotic potential of trichostatin A in human ovarian cancer cells (SKOV3). Int. J. Nanomed. 2017, 12, 7551-7575. [CrossRef] [PubMed]

72. Gurunathan, S.; Kalishwaralal, K.; Vaidyanathan, R.; Venkataraman, D.; Pandian, S.R.K.; Muniyandi, J.; Hariharan, N.; Eom, S.H. Biosynthesis, purification and characterization of silver nanoparticles using Escherichia coli. Colloids Surf. B Biointerfaces 2009, 74, 328-335. [CrossRef] [PubMed]

73. Yin, N.; Liu, Q.; Liu, J.; He, B.; Cui, L.; Li, Z.; Yun, Z.; Qu, G.; Liu, S.; Zhou, Q.; et al. Silver nanoparticle exposure attenuates the viability of rat cerebellum granule cells through apoptosis coupled to oxidative stress. Small 2013, 9, 1831-1841. [CrossRef] [PubMed]

74. Li, Y.; Guo, M.; Lin, Z.; Zhao, M.; Xiao, M.; Wang, C.; Xu, T.; Chen, T.; Zhu, B. Polyethylenimine-functionalized silver nanoparticle-based co-delivery of paclitaxel to induce HepG2 cell apoptosis. Int. J. Nanomed. 2016, 11, 6693-6702. [CrossRef] [PubMed]

75. Karlic, H.; Herrmann, H.; Varga, F.; Thaler, R.; Reitermaier, R.; Spitzer, S.; Ghanim, V.; Blatt, K.; Sperr, W.R.; Valent, P.; et al. The role of epigenetics in the regulation of apoptosis in myelodysplastic syndromes and acute myeloid leukemia. Crit. Rev. Oncol. Hematol. 2014, 90, 1-16. [CrossRef] [PubMed]

76. Takebe, M.; Oishi, H.; Taguchi, K.; Aoki, Y.; Takashina, M.; Tomita, K.; Yokoo, H.; Takano, Y.; Yamazaki, M.; Hattori, Y. Inhibition of histone deacetylases protects septic mice from lung and splenic apoptosis. J. Surg. Res. 2014, 187, 559-570. [CrossRef] [PubMed]

77. Banfalvi, G. Apoptotic agents inducing genotoxicity-specific chromatin changes. Apoptosis 2014, 19, 1301-1316. [CrossRef] [PubMed] 
78. Dong, C.; Zheng, H.; Huang, S.; You, N.; Xu, J.; Ye, X.; Zhu, Q.; Feng, Y.; You, Q.; Miao, H.; et al. Heme oxygenase-1 enhances autophagy in podocytes as a protective mechanism against high glucose-induced apoptosis. Exp. Cell Res. 2015, 337, 146-159. [CrossRef] [PubMed]

79. McAtee, C.O.; Berkebile, A.R.; Elowsky, C.G.; Fangman, T.; Barycki, J.J.; Wahl, J.K.; Khalimonchuk, O.; Naslavsky, N.; Caplan, S.; Simpson, M.A. Hyaluronidase hyal1 increases tumor cell proliferation and motility through accelerated vesicle trafficking. J. Biol. Chem. 2015, 290, 13144-13156. [CrossRef] [PubMed]

80. Sierra, M.I.; Rubio, L.; Bayón, G.F.; Cobo, I.; Menendez, P.; Morales, P.; Mangas, C.; Urdinguio, R.G.; Lopez, V.; Valdes, A.; et al. DNA methylation changes in human lung epithelia cells exposed to multi-walled carbon nanotubes. Nanotoxicology 2017, 11, 857-870. [CrossRef] [PubMed]

81. Qian, Y.; Zhang, J.; Hu, Q.; Xu, M.; Chen, Y.; Hu, G.; Zhao, M.; Liu, S. Silver nanoparticle-induced hemoglobin decrease involves alteration of histone 3 methylation status. Biomaterials 2015, 70, 12-22. [CrossRef] [PubMed]

82. Zhao, X.; Toyooka, T.; Ibuki, Y. Silver nanoparticle-induced phosphorylation of histone H3 at serine 10 is due to dynamic changes in actin filaments and the activation of Aurora kinases. Toxicol. Lett. 2017, 276, 39-47. [CrossRef] [PubMed]

83. Gurunathan, S.; Choi, Y.J.; Kim, J.H. Antibacterial efficacy of silver nanoparticles on endometritis caused by Prevotella melaninogenica and Arcanobacterum pyogenes in dairy cattle. Int. J. Mol. Sci. 2018, 19, 1210. [CrossRef] [PubMed]

(C) 2018 by the authors. Licensee MDPI, Basel, Switzerland. This article is an open access article distributed under the terms and conditions of the Creative Commons Attribution (CC BY) license (http:/ / creativecommons.org/licenses/by/4.0/). 